\title{
Business cycle comovement and labor market institutions: An empirical investigation
}

\author{
Raquel Fonseca * $\quad$ Lise Patureau ${ }^{\dagger} \quad$ Thepthida Sopraseuth ${ }^{\ddagger}$
}

March 2008

\begin{abstract}
This paper examines the impact of labor market institutions (LMI) on business cycle (BC) synchronization. We first develop a two-country right-to-manage model of wage bargaining. We find that, following a symmetric demand change, cross-country differences in LMI generate divergent responses in employment and output. We then investigate the empirical relevance of this result using panel data of 20 OECD countries observed over 40 years. Our estimation strategy controls for a large set of possible factors influencing GDP correlations, which allows to confront our results with those found in previous studies. Consistently with our theoretical results, we find that similar labor markets across countries tend to favor more their synchronized cycles. In particular, disparities in tax wedges yields lower GDP co movement. Besides, interactions between labor market institutions do matter, enhancing or dampening the effect of tax wedge divergence on $\mathrm{BC}$ synchronization. Our overall results suggest that the impact of distortions in demand-supply labor mechanism should be investigated in international business cycle models.
\end{abstract}

Keywords: International business cycle, Business cycle synchronization, Labor market institutions, Panel Data Estimation

JEL Classification Number : F42, C23, J32, J52

\footnotetext{
*RAND 1776 Main Street P.O. Box 2138 Santa Monica, CA 90407-2138, USA. e-mail: fonseca@rand.org

†THEMA, Université de Cergy-Pontoise Site des Chênes 1 UFR d'Économie et Gestion 33, boulevard du Port 95011 Cergy-Pontoise Cedex, France. e-mail: patureau@eco.u-cergy.fr.

${ }^{\ddagger}$ EPEE, CEPREMAP and PSE Jourdan, Departement d'Economie, Univ. d’Evry, 4 Bd F. Mitterand, 91025 Evry Cedex, France. e-mail: tsoprase@univ-evry.fr.

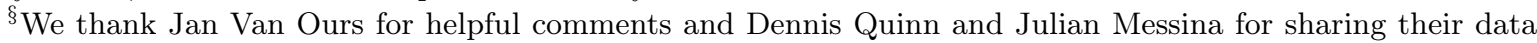
on capital account restrictions and service employment share, respectively. We thank audiences at EEA 2006 and LACEA-LAMES 2006.
} 


\section{Introduction}

What drives international GDP comovement? The extensive empirical literature on this topic has not reached a consensus yet. Frankel and Rose (1998) stress that trade matters. They present empirical evidence that higher bilateral trade is associated with more correlated business-cycles. Imbs (2004), Imbs (2001a) and Imbs (2001b) highlight another channel linked to similarity in industrial structure, while Engel and Rose (2002) stress the role of currency unions. Darvas, Rose, and Szarpary (2005) investigate the role of fiscal divergence across countries. They conclude that countries with similar budget positions tend to have more correlated business cycles. Baxter and Kouparitsas (2005) empirically investigate the robustness of such various variables. They find that all are considered as significant determinants of business-cycle comovement. However, when all variables are included in the regression, only a few of them are robust, namely bilateral trade consistently with Frankel and Rose's (1998) results. They deny a significant role to industrial similarity and currency unions, contrasting results are obtained by Imbs (2001a) and Engel and Rose (2002).

The question of what drives business cycle comovement remains an open issue. Our paper takes part to the debate. Its originality lies in assessing the impact of similarity in labor market institutions (LMI hereafter) on GDP cross-country correlation. If business cycles in OECD countries have been influenced by factors that are likely to favor comovement (trade and financial integration), one cannot neglect the potential role of other factors that may cause them to evolve differently. In this respect, one striking feature is the heterogeneity in the labor market regulations across OECD countries. Since the first oil shock in 1973, continental Europe, Japan and the USA have indeed evolved very differently regards their labor markets, which has called for different labor market policies. The empirical literature on determinants of international BC has not investigated this point.

International macroeconomic theory highlights the impact of labor market institutions on cross-country correlations. In Mundell's (1961) optimum currency area, member countries adjust to asymmetric shocks if workers are able and willing to move freely to other countries and if wages are flexible. Even if a single currency adoption often makes countries become gradually more alike, thus becoming itself more optimal (Frankel and Rose (1998)), disparity in LMI could hamper this convergence. Mundell (1961) addresses the normative implications of the issue, with the question of the "good" (and bad) labor market institutions. Mundell calls for a greater labor market flexibility, an orientation also adopted by OECD (1994) and reaffirmed in OECD (2005). The question we address here is not normative but positive: how does similarity in labor market regulations affect business cycle comovement?

The objective of the paper is twofold. First, we are particularly interested in the link between similarity in labor market regulations and business-cycle comovement. We thus develop a WS-PS model in a two-country setting to highlight the mechanisms through which differences in 
LMI affect business cycle synchronization. The partial equilibrium model extends Belot and Van Ours's (2004) right-to-manage model to an open economy framework. It shows that, following a symmetric demand change, cross-country differences in LMI generate divergent responses in employment and output. We then evaluate the empirical relevance of this result. For our empirical results to be convincing, we gauge whether they are robust to the inclusion of other potential determinants of $\mathrm{BC}$ comovement. Our second and related objective is therefore to evaluate the robustness of the various candidates of $\mathrm{BC}$ synchronization found in previous empirical works.

The estimations are based on data covering 20 industrialized countries over the period 19642003. Our estimation strategy puts into perspective the results obtained by Imbs (2004) and Baxter and Kouparitsas (2005), that use cross-section analysis, hereby discarding the specific time-varying dimension in their data. This is a serious limit of the methodology as it is likely to give spurious interpretations of the coefficients associated with control variables, in particular when covering such a long time horizon. In contrast with these papers, we estimate the effects of LMI similarity on BC synchronization by exploiting time series variation as well as cross-sectional variance, as in Darvas, Rose, and Szarpary (2005). With respect to this paper, we consider a larger set of control variables.

Our empirical results suggest that cross-country divergence in LMI reduces BC synchronization, notably differences in tax wedges. Moreover, in line with the conclusions drawn by Belot and Van Ours (2004) and Daveri and Tabellini (2000) on employment performances, we find that interactions between LMI do matter. Moreover, we find that interactions between LMI affect the single effect of tax wedge divergence on $\mathrm{BC}$ synchronization. In the particular case of the Euro zone, our overall results then give support to the view that harmonization in labor market institutions can ease the conduct of monetary policy within the area. With respect to the other determinants of $\mathrm{BC}$ synchronization, we find that industrial similarity does not significantly affect GDP comovement as in Baxter and Kouparitsas (2005). In addition, trade matters. However, the relevant trade measure in explaining GDP comovement is similarity in imported goods. Our results also support Darvas, Rose, and Szarpary (2005)'s conclusions on the role of fiscal convergence in generating more synchronized cycles.

The rest of the paper is structured as follows. Section 2 is devoted to the theoretical model. Section 3 presents our dataset and descriptive statistics. In Section 4, we present our estimation strategy and the results of our benchmark regressions. They confirm that LMI matter in business cycle synchronization. In particular, disparity in tax wedges yields lower GDP comovement. In Section 5, we explore the role of interactions between LMI in accounting for BC comovement. Section 6 concludes. 


\section{A two-country model with right-to-manage wage bargaining}

This section studies how cross-country differences in LMI may affect national labor market equilibria, thereby inducing asymmetric responses in output. We extent the partial-equilibrium closed-economy model developed by Belot and Van Ours (2004) to a two-country setting. In a right-to-manage model of wage bargaining, they establish the link between LMI and the equilibrium levels of wage and employment. Our modelling is quite similar to theirs on this point, hence we do not go through the analytical derivation of the WS-PS model in order to focus on the open economy dimension.

\subsection{WS-PS in an open economy}

Country 1 (country 2 respectively) is referred to as the "domestic country" ("foreign" respectively). In what follows, we focus on country 1 . The situation in country 2 may be inferred by symmetry, since we assume that both countries are similar. They differ only on the calibration of their LMI.

The right-to-manage model of wage bargaining relies on the assumption that wages are set by a bargaining process between a union and a firm, so as to maximize the relative surplus of both players. In each country $i=\{1,2\}$, there are a number $n_{i}$ firms in monopolistic competition (assumed to be symmetric), and $n_{i}$ unions. Each union negotiates wages with one firm, the bargaining process being independent of the other unions and firms. The bargaining process can occur at various levels (firm-level, industry-level or national-level). The case when $n_{i}=1$ is the situation in which wage negotiations are centralized at the national level.

In each country, firms are in monopolistic competition in the production of differentiated final goods. We abstract from capital in the model to derive analytical solutions. Output $y_{1}(z)$ produced by a firm $z$ in country 1 is given by the following Cobb-Douglas specification:

$$
y_{1}(z)=l_{1}(z)^{\alpha}
$$

with $l_{1}(z)$ the employment level in firm $z$ (in country 1), and $0<\alpha<1$. Each domestic firm $z$ faces the following demand for its good coming from both countries:

$$
y_{1}^{d}(z)=p_{1}(z)^{-\eta} C_{W}
$$

where $\eta>1$ is the elasticity of substitution across varieties and $C_{W}$ is an exogenous parameter that represents aggregate demand at the world level. ${ }^{1}$ The optimizing problem may be decomposed into two steps. First, the wage level is negotiated within each union-firm pair. Secondly, given the resulting wage level, each firm optimally determines its labor demand. The problem is solved backwards.

\footnotetext{
${ }^{1}$ The demand function for good $z$ results from the household's standard optimizing problem with CES preferences (see Dixit and Stiglitz (1977)).
} 
(PS) curve Firm $z$ (in country 1) determines its employment level and its sale price so as to maximize its profits :

$$
\max _{p_{1}(z), l_{1}(z)} \pi_{1}(z)=p_{1}(z) y_{1}(z)-w_{1}(z)\left(1+\tau_{1}+f_{1}\right) l_{1}(z)
$$

given equations (1) and (2). $w_{1}(z)$ is the negotiated wage in firm $z$ and $\tau_{1}$ the labor tax rate. In addition, the firm has to incur firing costs per worker $w_{1} f_{1}$. Taking first-order conditions and imposing symmetry between firms within a country, we get the following Price Setting $(P S)$ schedule in country 1 :

$$
l_{1}=\left[\frac{(1-\mu) C_{W}}{w_{1 t}\left(1+\tau_{1}+f_{1}\right)}\right]^{\frac{1}{\mu}}
$$

with $\mu=1-\alpha(1-\eta) . \mu$ represents the effective degree of firms monopoly power, determining the magnitude of the price mark-up on wage costs. Equation (3) determines a labor demand curve as a decreasing function of the negotiated wage. Besides, an increase in aggregate demand $\left(C^{W}\right.$ goes up) results in an increased production, hence, a higher labor demand in country 1. A similar expression holds in country 2.

(WS) curve Both countries solve their union-firm bargaining. In country 1, the wage level in firm $z$ is determined according to a Nash-bargaining process between the firm and a union, so as to maximize the total surplus of the match $\Omega_{1}(z)$ :

$$
\max _{w_{1}(z)} \Omega_{1}(z)=\left[\Omega_{1}^{f}(z)\right]^{1-\beta_{1}}\left[\Omega_{1}^{e}(z)\right]^{\beta_{1}} \quad 0<\beta_{1}<1
$$

with $\Omega_{1}^{f}(z)$ the rent of firm $z, \Omega_{1}^{e}(z)$ the rent of a worker hired by firm $z$, and $\beta_{1}$ the bargaining power of unions, assuming symmetry across unions and across firms within a country. Belot and Van Ours (2004) provide a detailed analytical resolution of the problem. Using the symmetry condition, the equilibrium wage level in country 1, or the Wage-Setting $(W S)$ schedule, is given by:

$$
w_{1}=\left(1+\frac{\frac{\beta_{1} \mu}{1-\mu}}{1-\frac{l_{1}\left(n_{1}-1\right)}{n_{1}}\left(\frac{\beta_{1} \mu}{1-\mu}+1\right)}\right)\left(\frac{b_{1}}{1+q f_{1}}\right)
$$

$b_{1}$ is the benefit replacement ratio that intervenes as the worker's outside option in the Nashbargaining process, and $q$ is the exogenous job destruction rate, assumed to be similar across countries. $l_{1}$ is the equilibrium employment level resulting from the firm optimal decisions. It is perfectly anticipated at this step, given that both players are assumed to be perfectly informed about firms' behavior. In the centralized case $\left(n_{1}=1\right)$, the wage setting schedule simplifies to:

$$
\left.w_{1}\right|_{n_{1}=1}=\left(\frac{\beta_{1} \mu}{1-\mu}+1\right)\left(\frac{b_{1}}{1+q f_{1}}\right)
$$

As shown by equation (5), the negotiated wage is an increasing function of $\beta_{1}, n_{1}$ and $b_{1}$, whereas it decreases with $f_{1}$. Higher $\beta_{1}, n_{1}$ or $b_{1}$ give workers a better outside option in the 
wage bargaining process, leading to a higher negotiated wage value. The opposite reasoning holds for firing costs $f_{1}$.

Employment and output Wage bargaining (equation (5)) and labor demand (equation (3)) simultaneously determine the labor market equilibrium in each country $i=1,2$, that is $\left(w_{i}, L_{i}\right)$, with $L_{i}$ the sum of all individual labor demands of firms in country $i$. In a symmetric equilibrium, $L_{i}=n_{i} l_{i}$ with $l_{i}$ given by equation (3). The employment level in the centralized economy $\left(n_{i}=1\right)$ is then:

$$
\left.L_{1}\right|_{n_{1}=1}=\left[\frac{(1-\mu) C_{W}}{\left(\frac{\beta_{1} \mu}{1-\mu}+1\right)\left(\frac{b_{1}}{1+q f_{1}}\right)\left(1+\tau_{1}+f_{1}\right)}\right]^{\frac{1}{\mu}}
$$

For a given $C_{W}$, the bargaining power $(\beta)$, the effective degree of firms monopoly power $(\mu)$, the labor tax rate $(\tau)$, and the benefit replacement ratio $(b)$ have a negative effect on the equilibrium employment level, while firing cost $(f)$ have an ambiguous effect. Indeed, high values of $\beta$ and $b$, by raising workers' outside option, lead to a higher negotiated wage, which reduces optimal labor demand and the resulting equilibrium employment level. Similarly, for a given negotiated wage, a heavy tax rate $\tau$ reduces labor demand (equation (3)). Firing costs $f$ have an ambiguous impact on employment. On the one hand, for a given negotiated wage, they increase the firms labor cost, hence reducing optimal labor demand (PS effect, equation (3)). On the other hand, they strengthen the firm's bargaining power in the wage negotiation, leading to a reduced negotiated wage level (WS effect, equation (5)). Finally, one can show that the employment level decreases with $n$ (see Belot and Van Ours (2004)).

Equation (7) also shows that labor market institutions interact with each other, as the impact of any LMI parameter on employment is affected by the values taken by the other labor market regulations. As in Belot and Van Ours (2004), any LMI that depresses the level of employment also reduces its sensitivity to another LMI change. For instance, the employment effect of a change in labor tax $\tau$ is reduced if the country is characterized by strong trade unions (high $\beta$ ) or generous unemployment benefits (high $b$ ).

Aggregate output is $Y_{i}=n_{i} y_{i}$ with $y_{i}$ given by equation (1). In the centralized case, domestic aggregate production $Y_{1}$ is given by:

$$
\left.Y_{1}\right|_{n_{1}=1}=\left[\frac{(1-\mu) C_{W}}{\left(\frac{\beta_{1} \mu}{1-\mu}+1\right)\left(\frac{b_{1}}{1+q f_{1}}\right)\left(1+\tau_{1}+f_{1}\right)}\right]^{\frac{\alpha}{\mu}}
$$

A similar expression holds in the foreign country. Equation (8) therefore establishes the link between LMI and national equilibrium output, for a given value of aggregate demand $C_{W}$. 


\subsection{The impact of an exogenous change in demand}

Do divergence in LMI lowers cross-country comovement? In that section, we address the question using the theoretical framework described in the previous sections. To that aim, we analyze the effects of an increase in the demand for goods that affects both countries. The only source of asymmetry comes from LMI. In that context, we show that divergence in labor market institutions causes economies to respond differently, even after a common shock.

We adopt a partial-equilibrium approach by modelling the common shock through an exogenous increase in $C^{W}$. The (WS)-(PS) system (equation (3), aggregated at the national level, and equation (5)) is then sufficient to determine the equilibrium values of $w_{i}$ and $L_{i}$ in each country $i=1,2$. Aggregate output is derived from equation (1). In order to simplify the exposition of the model, we examine the effects of the demand shock in the case of centralized wage bargaining. Our results are not qualitatively modified with $n_{i}>1$. The magnitude of the employment response to the demand shock stems from equation (7):

$$
\left.\frac{d L_{i}}{d C_{W}}\right|_{n_{i}=1}=\frac{1}{\mu} C_{W}^{\frac{1}{\mu}-1}\left[\frac{(1-\mu)}{\left(\frac{\beta_{i} \mu}{1-\mu}+1\right)\left(\frac{b_{i}}{1+q f_{i}}\right)\left(1+\tau_{i}+f_{i}\right)}\right]^{\frac{1}{\mu}}
$$

Equation (9) shows that the employment response to the common demand shock depends on the country-specific LMI $(\beta, \tau, b$ and $f)$. In particular, it is larger when the union bargaining power $\beta$, the labor tax $\tau$ and unemployment benefits $b$ are low. As well (and summarizing Belot and Van Ours's results), the lower degree of centralization in wage bargaining (i.e., the higher $n$ ), the lower the employment level. In contrast, the effect of firing costs $f$ is ambiguous.

Interaction between LMI also matter in the way economies adjust to the common shock. Consider for instance countries that differ in their tax wedges. According to equation (9), the magnitude of the employment change in the high tax rate country is more limited than in the low tax rate country. This implies some divergence in employment and output responses across countries, thereby reducing $\mathrm{BC}$ comovement. Besides, if, for instance, the unions' bargaining power is strong in both countries ( $\beta_{1}$ and $\beta_{2}$ high), then the change in employment (following the common shock) is limited in both countries (equation (9)). In that context, following the demand shock, the cross-country divergent responses in employment and output due to heterogeneity in tax rates is reduced. This economic mechanism suggests to investigate the empirical role of interactions between LMI in the business cycle synchronization. This is done in Section 5.

In a two-country framework, equation (9) shows that the magnitude of the employment increase to a world demand change is more limited in the country with the most "rigid" labor market (high $b, \tau$ or $\beta$ ). As a result, a common demand shock yields a lower international output correlation when countries differ in their LMI. Figure 1 illustrates the underlying economic mechanisms following a change in world demand, when countries differ in the labor tax $\tau$ in the centralized case. The calibration of structural parameters is reported in Table 1. 
Given Basu and Fernald's mark-up estimates, the elasticity of substitution across varieties $\eta$ is set equal to 6. $\alpha$ is based on Kydland and Prescott (1982). Following Campolmi and Faia (2006), we set $\beta=0.5$. The exogenous job destruction rate $q$ is based on Kraus and Lubik (2003). The benefit replacement ratio $b$ is calibrated so as to match mean value in OECD countries (based on data provided by Nickell (2006), and later used in our database). The value of $f$ is set equal to 0.4 (that is the mean value of dismissals indices in OECD countries provided by Botero, Djankov, La Porta, Lopez de Silanes, and Shleifer (2004)). Asymmetry in LMI is introduced through tax rates. In the "flexible" country 1 , we set $\tau_{1}=0.33$, while in the "rigid" country 2 , we set $\tau_{2}=0.57$, so as to mimic the tax wedge values in the US and France respectively, based on data for OECD countries provided by Nickell and Nunziata $(2001){ }^{2}$

Figure 1: Comparative statics analysis

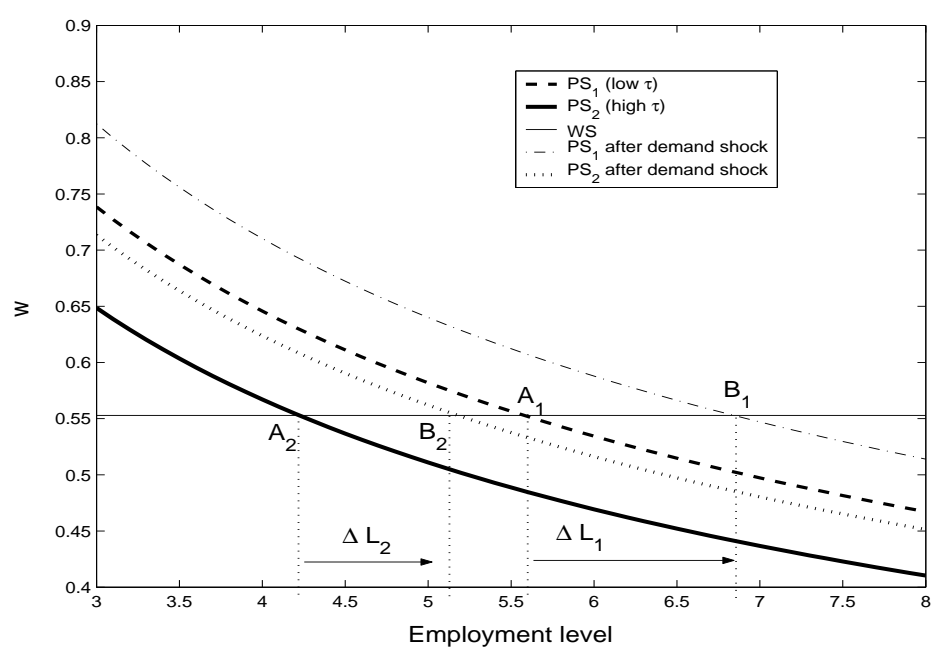

Consider first the labor market equilibrium before the change in aggregate demand. Given that wage bargaining is set at the centralized level, and that the LMI entering the wage setting process are similar across countries (equation $(5)$ ), the $(W S)$ curve is identical in the two countries and defines an unique negotiated wage level, independent of the employment level $((W S)$ is horizontal in Figure 1). Divergence in tax rates only affect labor demand. As shown by equation (7), a higher tax rate reduces labor demand. The resulting equilibrium employment level is lower in country 2 (point $A_{2}$ ) than in country 1 (point $A_{1}$ ).

Consider now the effect of a positive demand change $\left(d C_{W}>0\right)$, that is identical in both countries. The demand change shifts labor demand $(P S)$ upward. In the high-tax rate economy (country 2), firms are more reluctant to adjust the positive demand shock through quantities. As a consequence, the magnitude of the increase in labor demand is more limited in country 2 in

\footnotetext{
${ }^{2}$ To be consistent with the empirical analysis, calibration is based on tax wedge rather than on the employer's tax rate. Using the employer's tax rate would not qualitatively affect our results since France is still considered as more rigid than the US, according to the database on employer's tax provided by Nickell (2006).
} 
spite of a common shock (labor level goes up from $A_{2}$ to $B_{2}$ ). Employment and output increases are consequently more limited in the rigid economy than in the flexible economy $\left(\Delta L_{1}>\Delta L_{2}\right.$ as shown in Figure 1).

This analysis illustrates that employment hence output responses differ across countries because of divergence in LMI, even in case of common demand changes. Heterogeneity in LMI can actually lead to even more divergent output responses when exogenous changes are asymmetric across countries. The WS - PS model confirms our intuition that divergent LMI reduce GDP comovement. However, endogenous trade balance adjustments could reduce the magnitude of this effect. In a general equilibrium setting, differences in output responses indeed affect trade balances, hence terms of trade. Changes in terms of trade favor the demand for good produced in one country and lowers the demand for good produced by the other (expenditure switching effect). As a result, taking into account responses of international relative prices could reduce or enhance the divergence in output due to asymmetric LMI. This calls for an empirical investigation to assess whether similar LMI strengthen output comovement or not. This is done in the next sections.

\section{Do labor market institutions affect GDP comovement? A first look}

\subsection{Description of the dataset}

We use a panel of 20 OECD countries observed throughout 40 years, from 1964 to 2003. The complete list of countries is provided in Appendix A. The data is split into four decades (1964-73, 1974-83, 1984-93, 1994-2003) yielding a sample of 760 observations and 190 country pairs. Data sources and descriptive statistics of key variables are provided in Appendices B and C.

Business cycle synchronization is captured by the GDP cross-country correlations (denoted $\rho^{y}$ ), as standard in the International Business Cycle literature. We use quarterly GDP time series from BSDB OECD database (1964:1-2003:4). GDP business cycle is identified using Hodrick and Prescott's (1997) filter. The theoretical framework (Section 2) identifies the role of various dimensions of the labor market functioning that are likely to affect $\mathrm{BC}$ comovement. In our empirical analysis, they are captured by the following set of variables:

- Employment protection laws $(e p l)$ consists of laws, regulations and administrative decisions that constrain the contractual conditions under which a worker can be dismissed. Employment protection laws are considered to be a key factor in generating labor market inflexibility. They may be considered as a proxy for the firing costs $f$ in the model developed in Section 2.

- Net Union Density (udnet) measures the share of workers that are union members. It is intended to capture union bargaining power, that is $\beta$ in the model of Section 2, similarly 
as Belot and Van Ours (2004). ${ }^{3}$

- Bargaining Coordination (co) refers to mechanisms whereby the aggregate employment implications of wage determination are taken into account when wage bargains are struck. This may be achieved if wage bargaining is highly centralized or if there are institutions, such as employers' federations, which can assist bargainers to act in concert even when bargaining itself ostensibly occurs at the level of the firm or industry. This variable captures the role of $n$ in the model (a higher degree of coordination corresponding to a lower value of $n)$.

- Gross Benefit Replacement Rate (brr) as percent of working wage captures the degree of generosity of the unemployment insurance system. Benefit Replacement Rates come from OECD data.

- Tax Wedge $(t w)$ is interpreted as taxes that constitutes the wedge between the real product wage (labor costs per employee normalized on the output price) and the real consumption wage (after tax pay normalized on the consumer price index). We interpret this variable as capturing the role of $\tau$ in the model of Section 2 .

For all LMI indicators, we investigate the impact of their cross-country divergence on business cycle synchronization. This divergence is captured by the absolute difference in labor institutions such that:

$$
\operatorname{DiffLabor}_{i, j, t}=\mid \text { Labor }_{i, t}-\text { Labor }_{j, t} \mid
$$

where Labor $_{i, t}=e p l_{i, t}$, udnet $_{i, t}, c_{i, t}$, brr $_{i, t}$ or $t w_{i, t}$ in country $i$, and the equivalent in country $j$. A higher value is interpreted as a larger difference in LMI at the beginning of each decade $t$.

\subsection{Descriptive statistics analysis}

\subsubsection{Descriptive statistics of LMI variables}

To gauge whether cross-country differences in LMI affect GDP comovement, we first check that there is indeed some heterogeneity in LMI across the OECD countries of our sample. To that aim, Table 2 (top panel) reports a summary of the distribution across countries of our measures of labor market regulation. ${ }^{4}$ It confirms a substantial degree of heterogeneity in the OECD LMI,

\footnotetext{
${ }^{3}$ Note that in some OECD countries, results of bargaining between firms and unions are extended to non-union firms and employees. A low value of union density does not necessarily indicate a weak power of trade unions in that case. As underlined by Nickell, Nunziata, and Ochel (2005), union density only tells one part of the story, an element that one has to keep in mind when interpreting related results.

In addition, we proxy unions' power $(\beta)$ and centralization in bargaining $(n)$ using union density and the coordination degree index respectively. Belot and Van Ours (2004) provide panel data on union coverage and centralization degree but not for all countries in our sample. We consequently do not include these variables in the database.

${ }^{4}$ As detailed below, for each LMI it is the 1994-value that happens in the regressions (associated with decade 4). As a result, the LMI series (on a yearly basis) used in the descriptive statistics end in 1995.
} 
as shown by the strong dispersion around the mean for each LMI variable. Figure 2 confirms the large degree of variability in LMI across countries, by reporting the mean value of employment protection laws and tax wedge (over the whole period) for each country in the sample.

Figure 2: LMI across countries

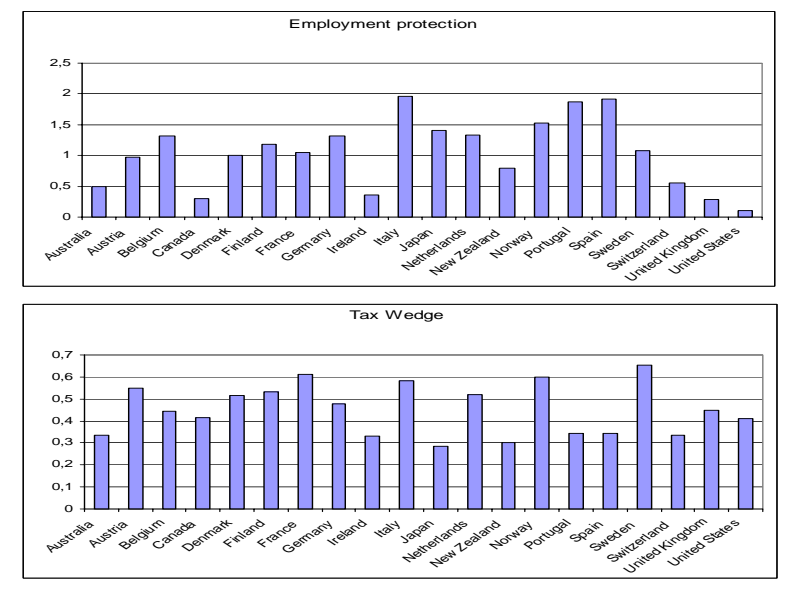

Next, we investigate the question of evolution of LMI over time. Descriptive statistics are presented in Table 2 (bottom panel). Most LMI evolve over time, union density and the degree of coordination of wage bargaining exhibiting a lower degree of variability. ${ }^{5}$ Evidence of timevariability in the labor market institutions thus supports our choice of implementing data-panel analysis, rather than in cross-section as Baxter and Kouparitsas (2005). A closer look at the data reveals that employment protection laws and tax pressure have changed substantially over the past decades. This is illustrated in Figure 3, that reports the yearly mean value of employment protection laws and tax wedge over the sample of countries. Both variables have been increasing since the beginning of the 1960s until the beginning of the 1980s to further decrease, notably tax wedge.

\subsubsection{A first look at the relation between LMI similarity and GDP comovement}

Does similarity in LMI enhance business cycle synchronization? We first address the question using descriptive statistics. Among the group of 20 countries, we identify some that may be qualified as "flexible" and others as "rigid". ${ }^{6}$ We then determine the cross-country GDP correlation over the period 1964 - 2003, for the whole set of countries and by country group. Results are displayed in Table 3.

In column I, we report the mean GDP correlation for the whole set of 20 countries. Columns

\footnotetext{
${ }^{5}$ As a result, one should keep in mind that the inclusion of a country-pair fixed effect in the regression may capture the effects of these two variables and make them insignificant in the regressions.

${ }^{6}$ The "flexible" group consists of Australia, Canada, Japan, the United States, the United Kingdom. The "rigid" group includes Finland, Germany, Italy, Norway and Sweden. This partition is based on a principal component analysis, that builds a synthetic LMI indicator as a linear combination of various LMI for each country.
} 
Figure 3: LMI over time
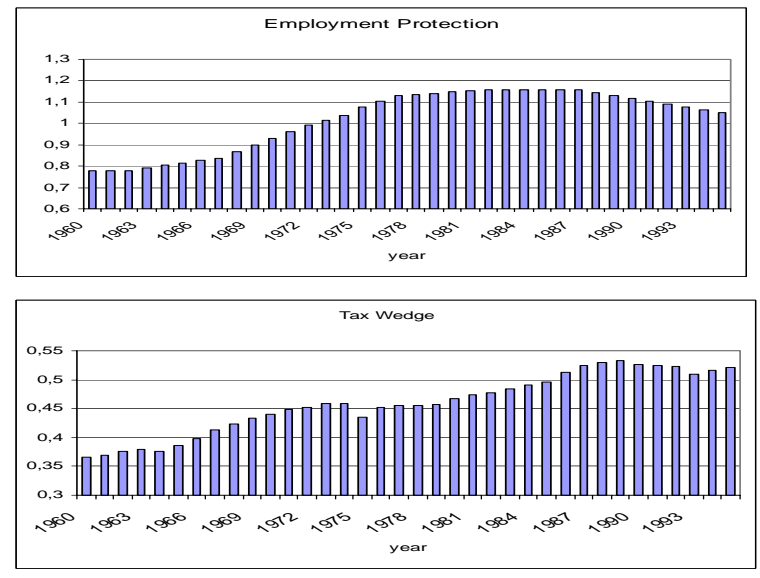

II and III present the same statistics, but obtained on a subset of countries with a similar functioning of the labor market (the group of "flexible" countries (column II) and the group of "rigid" countries (column III). In column IV, we make the opposite experiment by calculating the mean correlation between two countries with divergent LMI. Countries with a similar functioning of the labor market, either rigid or flexible, have more correlated business cycles than countries with divergent LMI. Results displayed in Table 3 comfort our intuition that LMI matter in business cycle synchronization.

Which LMI dimension mostly affect business cycle comovement? Table 4 presents the correlation between GDP comovement and cross-country divergence for each of our LMI variables, calculated over the whole period (on a decade-basis), all countries included. Disparity in tax pressure, in employment protection laws and in bargaining coordination significantly reduce the cross-country GDP correlation, the other variables are insignificant.

\section{Estimation strategy and empirical results}

Descriptive statistics analysis comforts us in our focus on the role of divergence in LMI on business cycle comovement. We now investigate the robustness of these preliminary results using panel estimation.

\subsection{Specification of the benchmark equation}

The benchmark regression is written as:

$$
\rho_{i, j, t}^{y}=\alpha+\gamma \text { Diff Labor }{ }_{i, j, t}+\kappa X_{i, j, t}+\omega_{i, j, t}
$$

with: 
- $\rho_{i, j, t}^{y}$ the cross country correlation of HP filtered GDP between country $i$ and country $j$ over decade $t$.

- Diff Labor $i, j, t$ the absolute difference in LMI between countries $i$ and $j$.

- $X_{i, j, t}$ a set of other variables that are likely to affect business cycle synchronization. Appendix B provides a full description of $X_{i, j, t}$ data.

- $\omega_{i, j, t}$ captures elements that influence GDP correlation, beyond the impact of LMI and $X_{i, j, t}$ variables, including time and country pair dummies as detailed below.

The paper aims at measuring how divergence in LMI affect international GDP correlations. As suggested by our theoretical model (Section 2) and descriptive statistics analysis (Section 3.2), we expect $\gamma$ to be negative as more similar labor markets favor bilateral activity comovement. However, in order to evaluate the robustness of the relationship, we need to check two elements related to the potential endogeneity between these variables. First, it has to be the case that the effect captured by differences in LMI is not attributable to an omitted variable that would lead to the same observed relationship between our explicative variable and the cross-correlation of outputs. Second, we need to check whether the causality goes in the right direction.

Regarding the first point, other variables (observable or unobservable) could be responsible for the negative relationship between the business cycle synchronization and differences in labor market institutions. This leads us to include a set of observable control variables $X_{i, j, t}$ that are likely to influence GDP comovement. Moreover, we cannot exclude the role of omitted variables that would jointly explain evolution in LMI and BC comovement. Such variables are typically factors specific to the couple of countries $i$ and $j$ that do not vary over time. For instance, historical links between countries $i$ and $j$, cultural proximity (such as common language), geographical proximity are likely to favor both convergence in LMI and business cycle synchronization. These elements are captured by the inclusion of a country-pair fixed effect in the regressions. It is consequently redundant to include time-invariant country-pair specific variables, typically gravity variables (such as distance, dummies indicating a common border, common language, colonial linkages, etc.). While gravity variables are commonly found to influence trade in the related empirical literature (Baxter and Kouparitsas (2006)), we capture their influence on BC synchronization by the fixed effect. Besides, dummies for each decade are included, to control for the intertemporal variability that is common to all country pairs in the sample. Consequently, the residual term $\omega_{i j t}$ of equation (11) is specified as follows:

$$
\omega_{i j t}=\mu_{i j}+\lambda_{t}+\varepsilon_{i j t}
$$

$\mu_{i j}$ is a country-pair fixed effect, i.e. it is invariant across time and specific for each country pair $\{i, j\} . \lambda_{t}$ stands for time-effect specific variables, and $\varepsilon_{i j t}$ is the "usual" residual with standard 
properties (mean equal to 0, homoskedastic, uncorrelated with itself, uncorrelated with: the fixed effects $\mu_{i j}, \lambda$ and any control variable). However, explanatory variables are allowed to be correlated with individual effects $\mu_{i j}$. Our choice of a fixed effect (versus a random effect model) is confirmed by a Hausman test.

The second problem related to endogeneity is reversed causality. It could indeed be argued that it is a closer synchronization in business cycles that is responsible for convergence in LMI. In our view, it is not likely to be the case that medium-run variables such as output cross-correlation affect the evolution of structural variables like LMI. Nevertheless, from an econometric point of view, the possibility of reverse causality should be controlled for. As a result, our measure of divergence in LMI for each country pair $\{i, j\}$ is based on the situation of both countries at the beginning of each decade, while the cross-country correlation in output is based on the mean of quarterly observations on the whole decade. Although it is not strictly speaking an instrumental variables method, it does control for reverse causality since differences in labor market protection at the beginning of the decade $(1963,1973,1983,1993)$ could hardly be explained by the joint behavior of output over the whole following decade. Our set of control variables $X_{i, j, t}$ refer to variables as observed at the beginning of decade $t$ as well. As argued by Baxter and Kouparitsas (2005), we relate our explanatory variables to the business cycle correlation over the subsequent sub-sample, so that the direction of causality is clear.

\subsection{Control variables}

If willing to put into evidence the impact of difference in LMI on business-cycle comovement in a convincing way, we have to show that it is robust to the inclusion of other variables that have been shown to be important determinants in that respect. Regressions will therefore include the following set of control variables.

Factor endowments We consider two factors of production, the stock of physical capital per worker $(K)$ and of arable land per worker $(L)$. Trade theory predicts a close relationship between factor endowments, trade and international business cycles. Specifically, the HeckscherOhlin theory predicts that country pairs should trade more, the more different are their factor endowments. The higher the minium factor endowments between the two countries, the stronger the comovement. The minimum factor endowment between the two countries must then display a positive and significant coefficient. Conversely, the maximum must have a negative and significant estimated coefficient. In order to compare our results to Baxter and Kouparitsas (2005)'s, we consider bilateral indicators of factor endowments that capture the maximum value of the variable between the two countries. We thus expect a negative coefficient associated with these variables.

Trade and trade agreements We consider different measures of trade intensity. 
- Bilateral trade intensity: The relation between business cycles and trade has been extensively debated, both theoretically and empirically. In the classical Ricardian theory as well as in New Trade theory (Helpman and Krugman (1985)), trade leads to an increase in sectorial specialization. If the source of shocks is sectorial, then trade should reduce the cross-country GDP correlation. Yet, it can also play a role as a transmission channel of exogenous changes that are common to the countries. Trade intensity should then lead to increased BC comovement. Empirically, most studies conclude that trade intensity is strongly and positively linked to BC synchronization (Frankel and Rose (1998), Canova and Dellas (1993), Baxter and Kouparitsas (2005) among others). We define a measure of bilateral trade intensity as the sum of bilateral exports and imports divided by total trade in countries $i$ and $j$. It is denoted "bilateral trade" in the regression results tables. More intensive bilateral trade is expected to enhance cross-country comovement.

- Total trade intensity: This variable is meant to capture the degree of openness of both countries, independently of the extent of bilateral trade between them. According to Baxter and Kouparitsas (2005), this variable may capture the flow of technological transmission that occurs through trade in general, not with a specific trading partner. Besides, it may be a good measure of the extent to which a country is exposed to global shocks. We thus expect that higher trade, in aggregate, leads to more correlated business cycles. As in Baxter and Kouparitsas (2005), the extent of total trade carried out by the pair of countries is computed as

$$
T T=\frac{x_{i}+m_{i}+x_{j}+m_{j}}{y_{i}+y_{j}}
$$

where $x_{i}$ and $m_{i}$ denote country $i$ 's total exports and imports measured at the beginning of each decade, and $y_{i}$ denotes country $i$ 's total GDP. We expect a positive sign associated with this variable (denoted "total trade"in the tables).

- Trade agreements: The existence of trade agreements is meant to increase the extent of trade among countries, as empirically shown by Frankel and Rose (1998) (among others). It is likely to enhance GDP cross-correlation as well. We build a dummy variable "Dum EU" to capture membership to the European Union, and we expect a positive sign.

Similarity in economic structure If the primary source of perturbations is sector-specific, then countries with greater similarity in economic structure should be more correlated, every thing else equal. Empirical literature gives some support to that assumption. According to Stockman (1988), sectorial changes are an important source of output fluctuations. Imbs (2001a), Imbs (2001b) obtain that similarity in industrial structure is positively and significantly related to BC comovement. We study the direct effect of economic similarity on business cycles synchronization through several variables. 
- Industrial similarity: As in Imbs (2001a), we use three-digit sectorial data (30 manufacturing sectors), to construct an index of manufacturing industry similarity for our 20 countries. Following Baxter and Kouparitsas (2005), we gauge the degree of international specialization using the following indicator:

$$
I S C=\frac{\sum_{k=1}^{K} s_{i k} s_{j k}}{\sqrt{\sum_{k=1}^{K} s_{i k}^{2}} \sqrt{\sum_{k=1}^{K} s_{j k}^{2}}}
$$

with $s_{i k}$ the fraction of manufacturing devoted to sector $k$ in country $i$, measured in terms of value-added as in Baxter and Kouparitsas (2005). By construction, ISC takes values between 0 and 1 . Similar economic countries are characterized by $I S C=1$, while divergent specialization yields a low value of $I S C$. We expect a positive coefficient associated with industry similarity.

- Similarity in the share of services: Messina (2005) documents remarkable differences in the relative sizes of the service employment share across countries with similar income per capita. In addition, the weight of the service sector in OECD countries has gone through considerable changes in the last decades. The average service employment share has increased from $45.8 \%$ at the beginning of the 1960 s to $66.3 \%$ in the early $1990 \mathrm{~s}$. By focusing on industrial structure only, one can miss part of the picture when gauging similarity in economic structure. We consequently examine the impact of divergence in service employment share, whose measure is built as follows:

$$
\text { Diff. in serv. } \text { share }_{i, j, t}=\mid \text { Service }_{i, t}-\text { Service }_{j, t} \mid
$$

where Service $_{i, t}$ denotes country $i$ service employment share at the beginning of decade $t$. In that case, we expect a negative sign associated with this variable (denoted "Diff. in serv. share") in the regressions.

- Similarity in baskets of traded goods: Baxter and Kouparitsas (2005) underline that, if countries export and/or import similar baskets of goods, then they would be affected similarly by changes to the world prices of their import and export goods. In addition, countries with similar baskets of traded goods would be affected similarly in the event of sector-specific changes hitting their export and/or import sectors. Following Baxter and Kouparitsas (2005), we build the following measure of similarity in trade:

$$
T S C=\frac{\sum_{k=1}^{K} s_{i k} s_{j k}}{\sqrt{\sum_{k=1}^{K} s_{i k}^{2}} \sqrt{\sum_{k=1}^{K} s_{j k}^{2}}}
$$

As $s_{i, k}$ denotes the sector $k$ 's share of country $i$ 's total imports, TSC identifies similarity in imports. ${ }^{7}$ We expect a positive sign of the coefficient associated with in the regressions.

\footnotetext{
${ }^{7}$ Baxter and Kouparitsas (2005) propose alternative measures of trade similarity, that are based on exports
} 
Economic policy variables Darvas, Rose, and Szarpary (2005) underline the role of fiscal convergence in $\mathrm{BC}$ comovement. We extend their analysis by investigating the role of the similarity in monetary policy as well. As a result, cross-country heterogeneity in fiscal and monetary policies is captured as follows:

- Our measure of fiscal divergence is the cross-country difference in the general government budget surplus $(+)$ or deficit (-), measured as a percentage of national GDP. The measured is averaged over 10 years of annual data for each decade and denoted "Diff. in budget" in the regression results tables.

- Disparity in monetary policy is measured as the average absolute value of short run interest rate differential (denoted "Diff. in int. rate" in the following tables). Convergence in monetary policy may also capture the monetary discipline associated with a pegged exchange rate.

As underlined by Darvas, Rose, and Szarpary (2005), the expected sign for both measures is ambiguous. In the presence of country-specific shocks, accommodating policies could actually result in having simultaneously cross-country divergence in economic policies and more synchronized cycles. In that case, the coefficient of our measure of economic policy similarity is expected to be positively signed. On the opposite, economic policy may constitute per se a source of asymmetrical shock across countries. In that case, divergence in economic policy reduces BC synchronization. Darvas, Rose and Szarpary's (2005) empirical results support this last case as they obtain a negative coefficient associated to fiscal divergence.

Restrictions to international capital flows We refer to Quinn's (1997) index of capital mobility, that takes values between 0 and 100, increasing in the degree of financial openness. We capture similarity in capital openness between countries $i$ and $j$ by considering the absolute difference in capital mobility index:

$$
\text { Diff. in }{\text { Quinn's } \text { index }_{i, j, t}=\mid \text { Capital }_{i, t}-\text { Capital }_{j, t} \mid}
$$

where Capital $_{i, t}$ refer to the Quinn (1997) index in country $i$. Imbs (2004) find evidence that financially integrated regions are significantly more synchronized. We then expect a negative sign associated with this variable (denoted "Diff. in Quinn's index" in the tables).

or on bilateral trade flows. We thus build these variables and investigate their role on $\mathrm{BC}$ comovement as well. Preliminary experiments led us to retain similarity in imports, as it yields the most significant coefficient. Descriptive statistic analysis goes in the same direction. Countries in our sample are characterized by low similarity on exports and total trade. The associated mean values amount to 0.28 and 0.21 respectively, over the 4 decades. In comparison, the mean value of import similarity is 0.65 . OECD countries are thus more similar with respect to their imports than with respect to their exports. There is thus little surprise that it is import similarity that matters most in business cycle comovement. 
The summary of the distribution of our control variables and their correlation with $\rho^{y}$ are displayed in Appendix C. Tables C2 and C3 display correlations across variables, with significant coefficients in bold and associated $p$-value in parenthesis. Several variables seem relevant in accounting for business cycle synchronization: bilateral trade, endowment in capital, fiscal convergence, import similarity and membership to the European Union. All significant correlation coefficients have the expected sign.

\subsection{Differences in labor market institutions and business cycle comovement}

Tables 5 and 6 display the results of various regressions for testing the impact of all labor market variables, when including control variables $X_{i, j, t}$.

Column I in Table 5 presents regression results when only differences in LMI are included as explanatory variables in the regression. Only differences in tax wedges appear significant and correctly signed, as divergence in tax wedges lower bilateral activity comovement. The remainder of Tables 5 and 6 indicates that this result is robust to the introduction of alternative control variables. Columns II through XI report regression results with the inclusion of control variables: endowment factors (II), bilateral trade (III), total trade (IV), dummy capturing membership to the European Union (V), industrial similarity (VI), similarity in manufacturing sector (VII), convergence in fiscal policy (VIII), convergence in monetary policy (IX), difference in service share employment (X) and in capital flow regulation (XI). In column XII (Table 6), we report regression results when all control variables are included (our "Benchmark regression" hereafter). ${ }^{8}$ Estimation results reported in Tables 5 and 6 show that countries with similar tax wedges tend to exhibit more synchronized cycles.

LMI We can hardly compare our results with the related literature for want of papers linking LMI to GDP comovement. Nevertheless, we can refer to results obtained in the labor market literature that focuses on the determinants of equilibrium unemployment level in OECD countries. First, it is worth mentioning that the empirical literature does not reach clear-cut conclusions on the key dimensions in LMI that affect employment performances (Layard and Nickell (1999), Pissarides (1998)). Yet, in both empirical and theoretical fields there is some consensus that the role of employment protection laws on the employment level is ambiguous. Empirical papers by Nickell, Nunziata, and Ochel (2005) and Scarpetta (1996) (among others) find no significant effect of employment protection laws on the unemployment level. Our result that divergence in employment protection laws does not significantly affect BC comovement is consistent with these conclusions.

\footnotetext{
${ }^{8}$ We control for multicollinearity, measured through a condition number, the ratio of the largest to the smallest characteristic roots of the moment matrix. Common practice suggests that multicollinearity becomes a potentially serious problem when the moment condition is in excess of 20. We check that regressions meet this requirement. Multicollinearity check drives us to exclude industry similarity $(I S C)$ and openness (Total trade). In simple regressions, these variables have not been found to significantly affect international business cycles.
} 
Second, regressions displayed in Tables 5 and 6 suggest that divergence in tax wedge across countries is the main channel through which LMI affect GDP comovement. This finding is consistent with preliminary descriptive statistics results (see Table 4). In addition, it is in line with empirical results obtained in the labor market literature. Most papers get a significant (positive) impact of tax wedge on unemployment in various OECD countries (Nickell (1998), Daveri and Tabellini (2000) (among others)). ${ }^{9}$ The effect may be rationalized by our WS-PS framework. Analysis driven in Section 2 shows that heavy tax rate limits the magnitude of employment response to aggregate shocks. Cross-country differences in tax rates imply asymmetric responses of employment and output, thereby reducing the international GDP correlation.

According to column I (Table 5), a reduction in tax wedge divergence of 10 percentage points - equal to one standard deviation in tax wedge divergence - around its mean tends to raise the correlation of business cycles between a pair of countries ceteris paribus, by around 0.08 . With an average GDP correlation of 0.198 , this is a non-negligible effect. The effect remains significant when controlling for a larger set of determinants of business-cycle comovement (Column XII, Table 6). In that case, ceteris paribus a reduction in tax wedge divergence of 10 percentage points around its mean tends to raise the GDP cross-country correlation by around 0.07 . This is a sizeable effect. To compare with, a one standard-deviation reduction in fiscal divergence ("Diff.in budget") increases GDP comovement around 0.055 .

Control variables Regarding the estimated effects of our set of control variables on GDP comovement, we get results consistent with the literature, as all significant control variables appear correctly signed.

Factor endowments yield a negative sign when they are the only control variables included (column II, Table 5). This is also the case in the benchmark regression (column XII, Table 6). This result is consistent with Baxter and Kouparitsas (2005) who underline the major role of factor endowments in accounting for bilateral synchronization. Precisely, as in Baxter and Kouparitsas (2006), we find that it is the difference in land that matters most.

Unlike Baxter and Kouparitsas (2005), we do not find any significant role of similarity in capital restrictions (columns X and XII, Table 6). This may be due to a selection bias in the country sample. While they explore business cycle comovement among developed and developing economies, our study focuses on OECD countries, which are already open to capital flows. Given our countries sample, it is not so surprising that the impact of financial openness on bilateral output synchronization is estimated weak.

The result that fiscal convergence favors international comovement is consistent with Darvas, Rose, and Szarpary (2005) (column XII, Table 6). Our point estimate for fiscal convergence (-0.019) also matches their own results (when they include country fixed effects). In addition, we

\footnotetext{
${ }^{9}$ Even if some studies indicate that employment taxes have no long run impact on unemployment (Baccaro and Rei (2005), OECD (1990), Appendix 6).
} 
find that similarity in monetary policy significantly matters as well (columns IX and XII, Table 6). Our paper strengthens Darvas, Rose and Szarpary's (2005) findings, as we control for many more possible influences on our dependant variable. Besides, we show that fiscal convergence remains significant in spite of the inclusion of monetary policy variable. Disparity in fiscal and monetary policies lowers international comovement.

The related empirical literature does not reach some clear-cut consensus regards the role of bilateral trade and industrial similarity. Imbs (2001a) highlights the role of industrial similarity $(I S C)$ as a major factor in BC synchronization, while Baxter and Kouparitsas (2005) insist on the key role of bilateral trade, as Darvas, Rose, and Szarpary (2005). ${ }^{10}$ In our benchmark regression, none of these variables is found to be significant. The role of similarity in service share is not robust either to the inclusion of a larger set of control variables. Several elements might account for our results.

- First, the weak influence of bilateral trade may be due to the fixed effect specification, given the inclusion of decade dummies and country-pair fixed effects. Section 4.4 investigates that point.

- Secondly, we find that similarity in the baskets of imported goods $(T S C)$ is significantly and positively correlated with GDP comovement. In our view, our results somehow reconcile Baxter and Kouparitsas (2005) and Imbs (2001a) on the respective roles of trade and economic similarity. Given the increase in intra-firm trade over the last decades (Antras (2006)), similarity in imports may capture the role of trade in BC comovement. Besides, the role of similarity in the import basket in $\mathrm{BC}$ comovement may be suggestive of the importance of sectorial shocks. With convergent sectorial structures, similarity in the structure of manufactured good consumption is likely to enhance GDP comovement.

\subsection{Robustness analysis}

We explore the robustness of our findings to the role of time and country-pair dummies. The estimated effects of cross-country differences in tax wedges on GDP comovement are robust to these changes, as shown in Table 7 . It reports regression results when we exclude decade dummies (column II), country-pair fixed effects (columns III and IV), and both (column V). For sake of comparison, column (I) recalls our benchmark regression (Table 6, column XII).

Baxter and Kouparitsas (2005), Frankel and Rose (1998) (among others) stress the role of bilateral trade intensity in enhancing BC comovement. In contrast, our benchmark results suggest that bilateral trade is not a significant determinant of $\mathrm{BC}$ synchronization (Table 6 , column XII). One potential explanation may be linked to the inclusion of time and country pair fixed effects. Time dummies are likely to capture the gradual liberalization in trade since the

\footnotetext{
${ }^{10}$ Yet, Darvas, Rose, and Szarpary (2005) do not investigate the role of economic similarity.
} 
early 1960s. Besides, the country-pair fixed effects capture gravity variables, which are commonly found to drive bilateral trade. In that respect, changes in the model's specification may affect our benchmark result. Yet, results reported in Table 7 confirm that bilateral trade is not a driving force behind GDP synchronization. Except when neither decade dummies nor country-pair fixed effects are included (Column V), the variable of bilateral trade appears insignificant.

Interestingly, we get that cross-country differences in the degree of coordination in wage bargaining significantly reduce $\mathrm{BC}$ synchronization when country-pair fixed effects are suppressed: In columns III to V, the coefficient associated with "Diff. in $c o$ " is significantly negative. This suggests that the wage-negotiating process constitutes another channel through which heterogeneity in LMI affect BC comovement. As shown by descriptive statistics, the degree of coordination displays low degree of variability, and its effect is not robust to the inclusion of fixed effects.

As a whole, Table 7 confirms the robustness of our results. The significant determinants of $\mathrm{BC}$ comovement that we previously identified remain. In most cases, coefficients associated with cross-country differences in labor taxation systems, in factor-endowments $(M A X L)$, in governmental policies ("Diff. in budget" notably) and in import similarity $(T S C)$ remain of the same sign and significant.

\section{Exploring the role of interactions across LMI variables}

Labor market studies point out that institutions interact with each other in the determination of unemployment dynamics (Daveri and Tabellini (2000), Belot and Van Ours (2004)). Our theoretical analysis (Section 2) indicates that interactions between LMI also affect GDP international comovement. This section investigates that point empirically.

Before commenting the estimation results, we present the interaction variables. We are primarily interested in measuring how the effect of tax wedge differential on $\mathrm{BC}$ comovement is affected by the degree of cross-country similarity regards other LMI. We thus include dummy variables that identify a similar labor market functioning in the two countries of a given pair. Precisely, we choose to identify the effect of a "rigid" labour market in both countries, rather than the one of "flexible" labor market regulations in the country pair. The theoretical model indeed implies that the effect of tax wedge difference on GDP comovement can be dampened in case of generous unemployment benefits $(b)$, low trade union coordination $(n)$ and high trade union bargaining power $(\beta)$. The effects are less clear-cut with regards to firing costs $(f)$. In this analysis, we want to identify potential labor market situations where our tax wedge effect might be moderated by the other LMI.

In a first step, we build a dummy variable that identifies rigidity of the labor market in each dimension of the labour market institutions. The dummy variable is country-specific and decade-specific. For instance, one country (in a particular LMI dimension) can be identified as "non rigid" in the first decade and "rigid" in the subsequent periods. Except for the degree of 
coordination of wage bargaining, we identify a country as "rigid" if its LMI value is superior to the threshold value of 1.6 times the median value obtained over the whole country sample. ${ }^{11}$ We proceed the other way round regards the degree of coordination, as our theoretical results indicate that a low degree of coordination (i.e., $n$ large) is likely to dampen the impact of tax wedge difference on GDP comovement. In that case, the dummy identifies countries with a coordination degree inferior to the threshold value of 0.4 times the median value obtained on the whole country sample.

In a second step, we build a dummy indicating if the two countries of a given country pair are "rigid" in each LMI dimension. For instance, the dummy "Both epl rigid" equals 1 if both countries have stringent employment laws, and 0 otherwise (if one or the two countries are below the threshold value).

This allows us to investigate the potential role on $\mathrm{BC}$ comovement, of 1) being similar and rigid along each LMI dimension per se, and 2) in interaction with divergence in tax wedge. In the first case, we focus on the estimated coefficient of the dummy, say "Both epl rigid". In the second case, we focus on the coefficient associated with the interaction variable. For instance, the variable denoted "Diff in $t w^{*}$ Both $e p l$ rigid" measures the marginal impact of differences in tax wedge on GDP correlation, conditional on the fact that the country pair $\{i, j\}$ has strong employment protection laws.

We first investigate the role of each dimension of LMI in interaction with tax wedge differences, before deriving the results when all interaction effects are included in the regression. Results are displayed in Table 8. In column I, we include the dummy "Both epl rigid", per se and in interaction with tax wedge differences ("Diff in $t w^{*}$ Both $e p l$ rigid"). We then repeat the analysis on the degree of coordination (column II), union density (III) and generosity of unemployment benefits (IV). In column V, all interacting LMI variables are included in the regression. In that case also, the dummy "Both $t w$ high" identifies if the two countries within a pair have heavy tax rates. In each case, we include control variables that have been shown to be robust determinants of $\mathrm{BC}$ comovement.

Two results emerge. First, the significant determinants of BC synchronization that we previously identified remain. Differences in tax wedge, in fiscal and monetary policy, in factor endowment, as well as similarity in imports significantly account for BC comovement. Secondly, interactions between LMI are found to affect GDP correlation, along two dimensions: union density (udnet) and employment protection (epl).

Let us first consider the role of union density. As shown in column III (confirmed in column $\mathrm{V}$ ), the fact that both countries have a strong union density reduces the effect of divergence in tax wedge on GDP comovement, as the coefficient associated with "Diff in tw* Both udnet high" is significantly positive. This result is consistent with our theoretical model. Indeed, the higher

\footnotetext{
${ }^{11}$ This threshold value results from an arbitrage between $i$ ) identifying countries with the more stringent LMI, and ii) having enough point estimates for the dummy.
} 
the union density ( $\beta$ in the model), the higher the workers' bargaining power. Every thing else equal, this pushes the negotiated wage up and reduces the labor demand, hence its sensibility to other labor market institutions. Our estimated coefficient on "Diff in $t w *$ Both udnet high" is consistent with this theoretical mechanism. The effect of an international harmonization of tax wedge on GDP synchronization is moderated by the presence of strong unions in both countries.

As for employment protection laws, the theoretical model states that employment protection regulations (i.e. firing costs $f$ ) have an ambiguous effect on the employment level. As a form of substitute for wage compensation in the bargaining process, high firing costs lower the equilibrium wage, which increases labor demand and its sensitivity to other LMI (WS effect). In contrast, firing costs as an element of labor cost, lower employment (PS effect). Belot and Van Ours's (2004) empirical results on OECD countries suggest that employment protection affects unemployment dynamics through the WS effect: higher firing costs increase employment and its responses to other LMI. Our estimates are consistent with these findings when we consider GDP cross country correlations (Table 8 , columns I and V). The fact that both countries have strong employment protection laws significantly enhances BC comovement (the coefficient associated with "Both epl rigid" is significantly positive) and magnifies the negative impact of tax-wedge differences on cross-country GDP correlation (the coefficient associated with "Diff in $t w^{*}$ Both epl rigid" is significantly negative). The impact of tax wedge difference on GDP comovement is larger when both countries are characterized by stringent employment protection laws, which is consistent with the WS effect of firing costs in our model.

There is some broad consensus in the labor market literature, that complementarities between LMI matter in the labor market performance. Our estimates extend this result in the field of international business cycles. Table 8 suggests that employment protection laws and trade unions' power interact with labor fiscal policy, in affecting cross-country GDP comovement. Moreover, the direction of the interacting effect is non-trivial, as the interacting variable may enhance or dampen the single effect of tax wedge divergence on $\mathrm{BC}$ synchronization. The underlying complexity between the various dimensions of the labor market regulations and their role on $\mathrm{BC}$ comovement, is rationalized by our open-economy WS-PS model.

\section{Conclusion}

The originality of the paper lies in assessing the impact of LMI on business cycle synchronization using panel techniques, thereby exploiting the time dimension as well as the cross section dimension of the variance in the data. The driving forces behind cross country output correlations have been extensively documented. Yet, little is known about the impact of institutions on international comovement. This paper aims at filling this gap, focusing on labour market institutions (LMI). Furthermore, our estimation strategy controls for a large set of possible factors influencing GDP correlations, which allows to confront the results with those found in previous 
studies.

Our main results can be summarized as follows. (i) Cross-country heterogeneity in LMI matter. In particular, disparity in tax wedges yields lower GDP comovement. Sensitivity analysis confirms that this result is robust. (ii) Interactions between LMI matter as well. In particular, the effect of tax wedge difference on GDP comovement is affected by similarity in employment protection and trade unions's bargaining power. (iii) Darvas, Rose, and Szarpary (2005)'s findings on fiscal convergence are found to be robust to the inclusion of a larger set of control variables. Furthermore, we provide new evidence that convergence in monetary policy matters as well. (iv) As in Baxter and Kouparitsas (2005), similarity in industrial structure does not appear significant. In addition, trade matters. However, the relevant trade measure in accounting for OECD GDP comovement is import similarity. This robust result indicates that similar terms of trade changes enhance cross country output correlations.

In this paper, we establish that labour market institutions affect international output fluctuations in OECD countries. This result suggests that the impact of LMI in international business cycle shall be investigated in international dynamic stochastic general equilibrium models. Campolmi and Faia (2006) and Holt (2004) provide interesting contributions on this issue. However, they discard disparity in labor taxation that is found to matter in accounting for GDP comovement. This is left for future research.

\section{References}

Antras, P. (2006): "Advanced Topics in International Trade," Discussion Paper 2535.

Baccaro, L., AND D. Rei (2005): "Institutional Determinants of Unemployment in OECD Countries: A Time Series Cross-Section Analysis (1960-98)," Discussion Paper DP/160/2005, ILO.

BARro, R., And J. LeE (2001): "International Data on Educational Attainment: Updates and Implications," Oxford Economic Papers, 53(3), 541-63.

Basu, S., and J. Fernald (1997): "Returns to Scale in U.S. Production: Estimates and Implications," Journal of Political Economy.

Baxter, M., and M. Kouparitsas (2005): "Determinants of Business Cycle Comovement: A Robust Analysis," Journal of Monetary Economics, 52, 113-157.

— (2006): "What determines Bilateral Trade Flows," Working Paper 12188, NBER.

Belot, M., And J. VAn Ours (2004): "Does the recent sucess of some OECD countries in lowering their unemployment rates lie in the clever design of their labour market reforms?," Oxford Economic Papers, 56(4), 621-642. 
Botero, J., S. Djankov, R. La Porta, F. Lopez de Silanes, and A. Shleifer (2004): "The Regulation of Labor," Quarterly Journal of Economics, 19, 1301-1338.

CAmpolmi, A., And E. FAiA (2006): "Cyclical Inflation Divergence and Different Labor Market Institutions in the EMU," Working Paper 619, European Central Bank.

Canova, F., and H. Dellas (1993): "Trade Interdependence and the International Business Cycle," Journal of International Economics, (34), 23-49.

Darvas, Z., A. Rose, and G. Szarpary (2005): "Fiscal Divergence and Business Cycle Synchronization : Irresponsibility is Idiosyncratic," Mimeo.

Daveri, F., And G. Tabellini (2000): "Unemployment, Growth and Taxation in Industrial Countries," Economic Policy, 30, 49-90.

Dixit, A., And J. Stiglitz (1977): "Monopolistic Competition and Optimum Product Diversity," American Economic Review, 67(3), 297-308.

Easterly, W., And R. Levine (2001): "What Have We Learned from a Decade of Empirical Research on Growth? It's Not Factor Accumulation: Stylized Facts and Growth Models," World Bank Economic Review, 15(2), 177-219.

Engel, C., And A. Rose (2002): "Currency Unions and International Integration," Journal of Money, Credit and Banking, 34, 1067-1089.

Feenstra, R., R. E. Lipsey, H. Deng, A. C. Ma, and H. Mo (2005): "World Trade Flows: 1962-2000," NBER Working Paper 11040, NBER.

Frankel, J., And A. Rose (1998): "The Endogeneity of the Optimum Currency Area Criteria," Economic Journal, 108(449), 1009-1025.

Helpman, E., and P. Krugman (1985): Market Structure and Foreign Trade. MIT Press, Cambridge, MA.

Hodrick, R., And E. Prescott (1997): "Post War US Business Cycles: an Empirical Investigation," Journal of Money, Credit and Banking, 29, 1-16.

Holt, R. (2004): "Exchange Rate Dynamics, Nominal Rigidities And Equilibrium Unemployment," Discussion Paper 47, Royal Economic Society Annual Conference.

IMBs, J. (2001a): "Co-Fluctuations," CEPR Discussion Paper 2267, CEPR.

(2001b): "Sectors and the OECD Business Cycle," CEPR Discussion Paper 2473.

(2004): "Trade, Finance, Specialization and Synchronization," Discussion paper, Mimeo. 
Inclan, C., D. Quinn, And M. Toyoda (2001): "How and Where Capital Account Liberalization Leads to Economic Growth," Mimeo, Georgetown University.

Kraus, M., and T. LubIK (2003): "The (Ir)relevance of Real Wage Rigidity in the New Keynesian Model with Search Frictions," Discussion paper, mimeo.

Kydland, F., and E. Prescott (1982): "Time To Build and Aggregate Fluctuations," Econometrica, 50, 1345-1370.

Layard, R., And S. J. Nickell (1999): "Labour Market Institutions and Economic Performance," in Handbook of Labor Economics, ed. by O. Ashenfelter, and D. Card. Amsterdam: North Holland.

Messina, J. (2005): "Institutions and Service Employment: A Panel Study for OECD Countries," LABOUR, 19, 343-372.

Mundell, R. (1961): "A Theory of Optimum Currency Area," American Economic Review, pp. 657-665.

Nickell, S. (1998): "Unemployment: Questions and Some Answers," The Economic Journal, 108, 1802-816.

Nickell, S., And L. Nunziata (2001): "Labour Market Institutions Database," Discussion paper.

Nickell, S., L. Nunziata, And W. Ochel (2005): "Unemployment in the O.E.C.D. Since the 1960s: What Do We Know?," The Economic Journal, 115, 1-27.

Nickell, W. (2006): "The CEP - OECD Institutions Dataset (1960-2004)," Discussion Paper 0759, Centre for Economic Performance.

OECD (1990): Employment Outlook. OECD, Paris.

— (1994): "The OECD jobs study. Facts, Analysis, Strategies," Discussion paper, OECD, Paris.

(2004): Benefits and Wages: O.E.C.D Indicators 2004. OECD.

(2005): "OECD Jobs Strategy: Lessons from a Decade's Experience," Discussion paper, OECD, Paris.

Pissarides, C. (1998): "The Impact of Employment Tax Cuts on Unemployment and Wages; the Role of Unemployment Benefits and Tax Structure," European Economic Review, 47, 155183. 
Quinn, D. (1997): "The Correlates of Change in International Financial Regulation," American Political Science Review, 91, 531-551.

SCARPETtA, S. (1996): "Assessing the role of labour market policies and institutional settings on unemployment: A cross-country study," .

Stockman, A. (1988): "Sectoral and National Aggregate Disturbances to Industrial Output in Seven European Countries," Journal of Monetary Economics, 21, 387-409. 


\section{Appendix}

\section{A Countries}

20 OECD countries are included in the sample: Australia, Austria, Belgium, Canada, Denmark, Finland, France, Germany, Ireland, Italy, Japan, the Netherlands, Norway, New Zealand, Portugal, Spain, Sweden, Switzerland, the United Kingdom, the United States.

\section{B Data sources}

The database was made from several sources.

- Cross country correlations for quarterly GDP and unemployment are based on OECD BSDB (1964:1-1999:4). Bilateral correlations are computed over 4 decades : 1964:1-1973:4 (decade 1), 1974:1-1983:4 (decade 2), 1984:1-1993:4 (decade3) and 1994:1-1999:4 (decade $4)$.

The set of explanatory variables spans a wide array of possible factors influencing cross country correlations. For all variables, observations at the beginning of each decade are included in the database. For instance, employment protection laws for decade 1 corresponds to the value observed in 1964, 1974 in decade 2, 1984 in decade 3 and 1994 in decade 4. We want to identify the impact of each variable on cross country correlations over the subsequent decade, thereby making the direction of causality clearer.

- LMI come from Nickell and Nunziata (2001), except gross benefit replacement rate that come from OECD Indicators on Benefits and Wages (OECD (1994)). See Table B1 for a description of LMI. 


\begin{tabular}{|c|c|c|}
\hline TABLE B1 & & \\
\hline Variable & Definition & Source \\
\hline $\begin{array}{l}\text { Employment Protection } \\
\text { Laws }(e p l)\end{array}$ & $\begin{array}{l}\text { Index range in 1-2. It consists of the laws, } \\
\text { regulations and administrative decisions that } \\
\text { constraint the contractual conditions under which } \\
\text { a worker can be dismissed; the laws and regulations } \\
\text { relating to the compensation an employer } \\
\text { is obliged to pay when regulations determining } \\
\text { remedies for wrongful or unfair dismissal. }\end{array}$ & Nickell and Nunziata (2001) \\
\hline $\begin{array}{l}\text { Net Union Density } \\
(\text { udnet })\end{array}$ & $\begin{array}{l}\text { The percentage of employees who are union } \\
\text { members. This variable is intended to capture } \\
\text { union bargaining power. }\end{array}$ & Nickell and Nunziata (2001) \\
\hline $\begin{array}{l}\text { Bargaining } \\
\text { coordination }(c o)\end{array}$ & $\begin{array}{l}\text { Index with range } 1 \text { through } 3 . \text { This index is } \\
\text { increasing in the degree of coordination in the } \\
\text { bargaining process on the employer's as } \\
\text { well as on the union's side. }\end{array}$ & Nickell and Nunziata (2001) \\
\hline $\begin{array}{l}\text { Gross benefit } \\
\text { replacement rate }(b r r)\end{array}$ & Percentage of working wage & OECD (2004) \\
\hline Tax wedge $(t w)$ & $\begin{array}{l}\text { Percent. This variable is equal to the sum of } \\
\text { the employer's tax rate (employer's social } \\
\text { security contributions as \% of wages } \\
\text { and salaries), the direct tax rate (amount of } \\
\text { direct taxes as \% of households' current receipts } \\
\text { and the indirect tax rate (total indirect tax of } \\
\text { as \% private final expenditures }\end{array}$ & Nickell and Nunziata (2001) \\
\hline
\end{tabular}

- Factor endowments:

- average years of schooling for total population (Source: Barro and Lee (2001))

- capital per worker using aggregate investment (Source: Easterly and Levine (2001))

- Land comes from FAO United Nations statistics (available at http://faostat.fao.org/faostat/)

- Population from Penn World (Tables 61).

- Measures of trade intensity

The computation of bilateral trade intensity ("BT") is taken from Darvas, Rose, and Szarpary (2005). Our measure of total trade intensity follows Baxter and Kouparitsas (2005). Data are taken from the NBER UN Trade Data base, available on the NBER website (Feenstra, Lipsey, Deng, Ma, and Mo (2005)).

- Similarity in economic structure are computed from three sources.

- Three-digit sectorial data are from United Nations Industrial Development Organization (UNIDO), and were used to construct an index of manufacturing industry similarity ("ISC") for our set of 20 countries in 1964, 1974, 1984 and 1994.

- As UNIDO data covers only manufacturing sectors, we want to supplement our measure of specialization with the service employment shares provided by Messina (2005). 
- Regards similarity in trade, we retain the same indicator as in Baxter and Kouparitsas (2005). Data are taken from the NBER UN Trade Data base, reachable through the NBER website (Feenstra, Lipsey, Deng, Ma, and Mo (2005)).

- Capital restrictions are based on Quinn (1997)'s updated database that is constructed from narrative descriptions in the IMF Annual Report on Exchange Arrangements and Exchange Restrictions (AREAER) regarding capital descriptions. This IMF annual report summarizes the laws governments use to govern international financial transactions. Quinn (1997) attempts to capture the intensity of enforcement of controls on both the capital account and the current account through a careful reading of the narrative descriptions in the AREAER. He scores the intensity of controls for capital account receipts and capital account payments separately. For each of these two categories, a score of 0 indicates payments are forbidden, 0.5 indicates that there are quantitative or other regulatory restrictions, 1 indicates that transactions are subject to heavy taxes, 1.5 indicates that there are less severe taxes, and 2 indicates that transactions are free of restrictions or taxes. The sum of the values for the two categories is an indicator of overall capital account openness that ranges between 0 and 4 , with 4 representing a fully open economy. The updated dataset we consider is used in Inclan, Quinn, and Toyoda (2001) and transform each measure into a 0 to 100 scale.

- Several variables are from Andrew Rose's webpage: currency union and regional agreement, Volume of bilateral trade.

\section{Descriptive statistics}

Table $\mathrm{C} 1$ presents descriptive statistics related to the distribution of our set of variables. Tables $\mathrm{C} 2$ and $\mathrm{C} 3$ display the correlation coefficient between our set of other control variables and crosscountry GDP correlation $\rho^{y}$. The figure in parenthesis below each correlation is its significance level. 


\begin{tabular}{|c|c|c|c|c|c|c|}
\hline \multicolumn{6}{|l|}{ TABLE C1 } & \\
\hline Variable & Obs & Mean & Std. Dev. & Min & $\operatorname{Max}$ & \\
\hline$\rho^{y}$ & 760 & 0.1981433 & 0.3526946 & -0.87744 & 0.9440 & \\
\hline Diff. in $e p l$ & 760 & 0.6762 & 0.4710 & 0 & 2 & \\
\hline Diff. in $t w$ & 741 & 0.1520 & 0.1073 & 0.00133 & 0.5512 & \\
\hline Diff. in $c o$ & 741 & 0.7145 & 0.5156 & 0 & 2 & \\
\hline Diff. in $u d n e t$ & 741 & \multirow{2}{*}{0.2092} & 0.1572 & 0.001 & 0.8091 & \\
\hline Diff. in $b r r$ & 760 & & 0.1107 & 0 & 0.5472 & \\
\hline Total trade & 760 & $\begin{array}{l}0.1450 \\
0.4361\end{array}$ & 0.2388 & 0.0858 & 1.3194 & \\
\hline Bilateral trade & 760 & 1.7965 & 2.7474 & 0.0314 & 26.060 & \\
\hline Dum EU & 760 & 0.2118 & $\begin{array}{l}2.7474 \\
0.4088\end{array}$ & 0 & 1 & \\
\hline$M A X L$ & 760 & -5.485 & 2.504 & -9.774 & -1.468 & \\
\hline$M A X K$ & 760 & 1.920 & 0.9612 & -2.206 & 3.046 & \\
\hline$I S C$ & 722 & 0.844 & 0.0860 & 0.4972 & 0.990 & \\
\hline$T S C$ & 760 & 0.6415 & 0.1742 & 0.17435 & 0.979 & \\
\hline Diff. in serv. share & 741 & 7.848 & 5.844 & 0.0168 & 31.838 & \\
\hline Diff. in budget & 760 & 3.585 & 2.407 & 0.4148 & 14.476 & \\
\hline Diff. in int. rate & 648 & 3.136 & 2.175 & 0.0581 & 12.649 & \\
\hline Diff. in Quinn's index & 760 & 20.082 & 17.285 & 0 & 87.5 & \\
\hline TABLE C2 & $\rho^{y}$ & TT & BT & Dum EU & $M A X L$ & $M A X K$ \\
\hline Total trade & $\begin{array}{l}0.0295 \\
(0.4169)\end{array}$ & 1.0000 & & & & \\
\hline Bilateral trade & $\begin{array}{c}\mathbf{0 . 1 7 6 3} \\
(0.00)\end{array}$ & $\begin{array}{r}-0.0963 \\
(0.0079)\end{array}$ & 1.0000 & & & \\
\hline Dum EU & $\begin{array}{c}\mathbf{0 . 1 6 3 0} \\
(0.00)\end{array}$ & $\begin{array}{c}0.2733 \\
(0.00)\end{array}$ & $\begin{array}{c}0.2497 \\
(0.00)\end{array}$ & 1.0000 & & \\
\hline$M A X L$ & $\begin{array}{r}-0.0330 \\
(0.3630)\end{array}$ & $\begin{array}{c}0.3934 \\
(0.00)\end{array}$ & $\begin{array}{r}-0.0320 \\
(0.3780)\end{array}$ & $\begin{array}{r}-0.1071 \\
(0.0031)\end{array}$ & 1.0000 & \\
\hline$M A X K$ & $\begin{array}{c}\mathbf{- 0 . 1 3 3 8} \\
(0.0002)\end{array}$ & $\begin{array}{c}0.3560 \\
(0.00)\end{array}$ & $\begin{array}{c}-0.3700 \\
(0.0000)\end{array}$ & $\begin{array}{c}-0.0843 \\
(0.0201)\end{array}$ & $\begin{array}{c}0.3542 \\
(0.00)\end{array}$ & 1.0000 \\
\hline$I S C$ & $\begin{array}{c}\mathbf{0 . 0 8 2 9} \\
(0.0259)\end{array}$ & $\begin{array}{c}-0.3063 \\
(0.00)\end{array}$ & $\begin{array}{c}0.3126 \\
(0.00)\end{array}$ & $\begin{array}{c}-0.0351 \\
(0.3465)\end{array}$ & $\begin{array}{r}0.0051 \\
(0.8918)\end{array}$ & $\begin{array}{c}-0.3406 \\
(0.00)\end{array}$ \\
\hline$T S C$ & $\begin{array}{c}\mathbf{0 . 2 4 4 5} \\
(0.00)\end{array}$ & $\begin{array}{c}0.0899 \\
(0.0132)\end{array}$ & $\begin{array}{l}0.1147 \\
(0.0015)\end{array}$ & $\begin{array}{c}0.2340 \\
(0.00)\end{array}$ & $\begin{array}{r}-0.0715 \\
(0.0487)\end{array}$ & $\begin{array}{r}-0.2339 \\
(0.0000)\end{array}$ \\
\hline Diff. in serv. share & $\begin{array}{c}-0.0258 \\
(0.4830)\end{array}$ & $\begin{array}{c}-0.1174 \\
(0.0014)\end{array}$ & $\begin{array}{c}-0.1512 \\
(0.0000)\end{array}$ & $\begin{array}{c}-0.0447 \\
(0.2243)\end{array}$ & $\begin{array}{c}-0.0702 \\
(0.0563)\end{array}$ & $\begin{array}{c}-0.2121 \\
(0.00)\end{array}$ \\
\hline Diff. in budget & $\begin{array}{r}-\mathbf{0 . 0 8 3 6} \\
(0.0212)\end{array}$ & $\begin{array}{c}0.1229 \\
(0.0007)\end{array}$ & $\begin{array}{r}-0.1177 \\
(0.0011)\end{array}$ & $\begin{array}{c}0.0005 \\
(0.9885)\end{array}$ & $\begin{array}{l}0.0784 \\
(0.0307)\end{array}$ & $\begin{array}{r}0.2395 \\
(0.00)\end{array}$ \\
\hline Diff. in int. rate & $\begin{array}{l}-0.0033 \\
(0.9339)\end{array}$ & $\begin{array}{c}-0.1716 \\
(0.00)\end{array}$ & $\begin{array}{c}-0.1684 \\
(0.00)\end{array}$ & $\begin{array}{c}-0.2223 \\
(0.00)\end{array}$ & $\begin{array}{c}-0.0047 \\
(0.9045)\end{array}$ & $\begin{array}{l}0.0334 \\
(0.3963)\end{array}$ \\
\hline Diff. in Quinn's index & $\begin{array}{r}-0.0036 \\
(0.9217)\end{array}$ & $\begin{array}{c}-0.2379 \\
(0.00)\end{array}$ & $\begin{array}{c}-0.0562 \\
(0.1213)\end{array}$ & $\begin{array}{c}-0.1693 \\
(0.00)\end{array}$ & $\begin{array}{c}-0.0290 \\
(0.4254)\end{array}$ & $\begin{array}{c}-0.1704 \\
(0.00)\end{array}$ \\
\hline
\end{tabular}




\begin{tabular}{l|ccccc}
\cline { 1 - 5 } TABLE C3 & $I S C$ & TSC & $\begin{array}{c}\text { Diff. in } \\
\text { serv. share }\end{array}$ & $\begin{array}{c}\text { Diff. in } \\
\text { budget }\end{array}$ & $\begin{array}{c}\text { Diff. in } \\
\text { int. rate }\end{array}$ \\
\cline { 1 - 5 } TSC & 0.0904 & 1.0000 & & & \\
Diff. in serv. share & $(0.0151)$ & & & & \\
Diff. in budget & -0.1735 & 0.0358 & 1.0000 & & \\
& $(0.00)$ & $(0.3303)$ & & & \\
Diff. in int. rate & -0.1859 & 0.1097 & 0.0463 & 1.0000 & \\
Diff. in Quinn's index & $(0.00)$ & $(0.0025)$ & $(0.2080)$ & & \\
& -0.1417 & 0.0478 & 0.2357 & 0.2356 & 1.0000 \\
& $(0.0004)$ & $(0.2242)$ & $(0.00)$ & $(0.00)$ & \\
& -0.0126 & 0.0259 & 0.2076 & -0.0876 & 0.2457 \\
& $(0.7361$ & $(0.4754)$ & $(0.00)$ & $(0.0157)$ & $(0.00)$ \\
\hline
\end{tabular}




\section{Tables}

Table 1: Calibration

\begin{tabular}{ccccccccc}
\hline$\alpha$ & $\beta$ & $b$ & $n$ & $\eta$ & $q$ & $f$ & $\tau_{1}$ & $\tau_{2}$ \\
\hline 0.64 & 0.5 & 0.40 & 1 & 6 & 0.1 & 0.4 & 0.33 & 0.57 \\
\hline
\end{tabular}

Table 2: LMI variables: some descriptive statistics over the period 1965-1995

\begin{tabular}{l|cccc}
\hline \multicolumn{5}{c}{ LMI distribution, across countries } \\
\hline Variable & Mean & Std dev. & Min & Max \\
\hline Empl. protection $(e p l)$ & 1.041 & 0.563 & 0.1 & 1.96 \\
Tax wedge $(t w)$ & 0.452 & 0.114 & 0.285 & 0.655 \\
Bargaining coord. (co) & 2.064 & 0.594 & 1 & 3 \\
Union density ( $u$ dnet) & 0.420 & 0.166 & 0.111 & 0.754 \\
Benefit repl. ratio (brr) & 0.385 & 0.137 & 0.096 & 0.630 \\
\hline \multicolumn{5}{c}{ LMI distribution, across time } \\
\hline Variable & Mean & Std dev. & Min & Max \\
\hline Empl. protection & 1.207 & 0.140 & 0.779 & 1.158 \\
Tax wedge & 0.460 & 0.052 & 0.3662 & 0.533 \\
Bargaining coord. & 2.068 & 0.013 & 2.036 & 2.082 \\
Union density & 0.418 & 0.026 & 0.386 & 0.460 \\
Benefit repl. ratio & 0.381 & 0.085 & 0.240 & 0.479 \\
\hline
\end{tabular}

Note: Time distribution has been calculated on a per-year basis.

Table 3: Cross-country GDP correlation, by country group

\begin{tabular}{c|cccc}
\hline & I & II & III & IV \\
& All countries & Flexible LMI & Rigid LMI & Flex - Rigid LMI \\
\hline$\rho^{y}$ & 0.1981 & $\mathbf{0 . 2 3 2 6}$ & $\mathbf{0 . 2 1 1 3}$ & 0.1476 \\
\hline
\end{tabular}


Table 4: Correlation between LMI similarity and BC comovement

\begin{tabular}{c|ccccc} 
& Diff. in $e p l$ & Diff. in udnet & Diff. in co & Diff. in brr & Diff. in $t w$ \\
\hline$\rho^{y}$ & $-0.0799^{*}$ & 0.0145 & $-0.1330^{*}$ & 0.0225 & $-0.0956^{*}$ \\
\hline
\end{tabular}

Notes: Spearman correlations on 20 country observations.

Notes: ${ }^{*}$ denotes statistical significance at the $5 \%$ level.

Table 5: Regression results (1)

\begin{tabular}{|c|c|c|c|c|c|c|}
\hline & \multicolumn{6}{|c|}{ Dependent variable: cross-country GDP correlation } \\
\hline & $\mathrm{I}$ & II & III & IV & $\mathrm{V}$ & VI \\
\hline \multirow[t]{2}{*}{ Diff. in epl } & -0.022 & -0.023 & -0.023 & -0.023 & -0.023 & -0.012 \\
\hline & $(0.663)$ & $(0.641)$ & $(0.653)$ & $(0.647)$ & $(0.649)$ & $(0.817)$ \\
\hline \multirow[t]{2}{*}{ Diff. in $t w$} & $-0.430^{* *}$ & $-0.426^{* *}$ & $-0.437^{* *}$ & $-0.413^{*}$ & $-0.488^{* *}$ & $-0.459^{* *}$ \\
\hline & $(0.045)$ & $(0.049)$ & $(0.044)$ & $(0.058)$ & $(0.030)$ & $(0.037)$ \\
\hline \multirow[t]{2}{*}{ Diff. in $c o$} & 0.058 & 0.04 & 0.058 & 0.056 & 0.055 & 0.061 \\
\hline & $(0.339)$ & $(0.516)$ & $(0.336)$ & $(0.356)$ & $(0.367)$ & $(0.321)$ \\
\hline \multirow[t]{2}{*}{ Diff. in $u d n e t$} & -0.058 & -0.048 & -0.063 & -0.057 & -0.041 & -0.004 \\
\hline & $(0.730)$ & $(0.777)$ & $(0.712)$ & $(0.735)$ & $(0.811)$ & $(0.983)$ \\
\hline \multirow[t]{2}{*}{ Diff. in $b r r$} & -0.047 & -0.039 & -0.048 & -0.028 & -0.052 & 0.041 \\
\hline & $(0.796)$ & $(0.829)$ & $(0.792)$ & $(0.879)$ & $(0.772)$ & $(0.832)$ \\
\hline$M A X L$ & & $\begin{array}{c}-0.323^{* * *} \\
\quad(0.015)\end{array}$ & & & & \\
\hline$M A X K$ & & $\begin{array}{l}0.022 \\
(0.856)\end{array}$ & & & & \\
\hline$I S C$ & & & & & & $\begin{array}{l}0.579^{*} \\
(0.069)\end{array}$ \\
\hline Dum EU & & & & & $\begin{array}{l}-0.047 \\
(0.407)\end{array}$ & \\
\hline Total trade & & & & $\begin{array}{c}0.12 \\
(0.656)\end{array}$ & & \\
\hline Bilateral trade & & & $\begin{array}{r}-0.006 \\
(0.841)\end{array}$ & & & \\
\hline Cst & $\begin{array}{c}0.240^{* * *} \\
(0.004)\end{array}$ & $\begin{array}{c}-1.595^{*} \\
(0.051)\end{array}$ & $\begin{array}{c}0.254^{* *} \\
(0.020)\end{array}$ & $\begin{array}{c}0.166 \\
(0.368)\end{array}$ & $\begin{array}{c}0.269^{* * *} \\
(0.003)\end{array}$ & $\begin{array}{r}-0.278 \\
(0.315)\end{array}$ \\
\hline Obs. & 723 & 723 & 723 & 723 & 723 & 687 \\
\hline$R^{2}$ & 0.035 & 0.045 & 0.035 & 0.035 & 0.036 & 0.044 \\
\hline$\frac{\sigma^{2}(\widehat{Y})}{\sigma^{2}(Y)}$ & 0.338 & 0.345 & 0.338 & 0.338 & 0.338 & 0.361 \\
\hline $\begin{array}{l}p \text {-values in parent } \\
* \text { significant at } 10 \\
\text { Country-pair fixed }\end{array}$ & $\begin{array}{l}\text { esis } \\
{ }^{* *} \text { significa } \\
\text { effects and } \mathrm{t}\end{array}$ & $\begin{array}{l}\text { t at } 5 \% ;{ }^{* * *} \\
\text { e dummies i }\end{array}$ & $\begin{array}{l}\text { gnificant at } \\
\text { luded but } n\end{array}$ & reported & & \\
\hline
\end{tabular}


Table 6: Regression results (2)

\begin{tabular}{|c|c|c|c|c|c|c|}
\hline \multirow[b]{2}{*}{ Model } & \multicolumn{6}{|c|}{ Dependent variable: cross-country GDP correlation } \\
\hline & VII & VIII & IX & $\mathrm{X}$ & $\mathrm{XI}$ & XII \\
\hline \multirow{2}{*}{ Diff. in epl } & -0.005 & -0.026 & -0.09 & -0.05 & -0.021 & -0.094 \\
\hline & $(-0.923)$ & $(0.610)$ & $(0.173)$ & $(0.336)$ & $(0.671)$ & $(0.170)$ \\
\hline \multirow[t]{2}{*}{ Diff. in $t w$} & $-0.526^{* *}$ & $-0.414^{*}$ & -0.311 & $-0.380^{*}$ & $-0.449^{* *}$ & $-0.478^{*}$ \\
\hline & $(-0.013)$ & $(0.053)$ & $(0.197)$ & $(0.082)$ & $(0.038)$ & $(0.058)$ \\
\hline \multirow[t]{2}{*}{ Diff. in $c o$} & 0.055 & 0.056 & 0.092 & 0.07 & 0.057 & 0.06 \\
\hline & $(-0.361)$ & $(0.356)$ & $(0.157)$ & $(0.250)$ & $(0.345)$ & $(0.352)$ \\
\hline \multirow[t]{2}{*}{ Diff. in $u d n e t$} & -0.077 & -0.051 & 0.014 & 0.071 & -0.049 & 0.159 \\
\hline & $(-0.645)$ & $(0.760)$ & $(0.943)$ & $(0.682)$ & $(0.769)$ & $(0.422)$ \\
\hline \multirow[t]{2}{*}{ Diff. in $b r r$} & -0.027 & -0.015 & 0.037 & -0.1 & -0.052 & 0.036 \\
\hline & $(0.881)$ & $(0.933)$ & $(0.859)$ & $(0.592)$ & $(0.776)$ & $(0.861)$ \\
\hline \multirow[t]{2}{*}{ Diff. in budget } & & -0.012 & & & & $-0.019^{* *}$ \\
\hline & & $(0.154)$ & & & & $(0.036)$ \\
\hline \multirow[t]{2}{*}{ Diff. in int. rate } & & & $-0.022^{*}$ & & & $-0.025^{* *}$ \\
\hline & & & $(0.061)$ & & & $(0.039)$ \\
\hline \multirow[t]{2}{*}{ Diff. in Quinn's index } & & & & & 0.001 & 0.001 \\
\hline & & & & & $(0.463)$ & $(0.256)$ \\
\hline \multirow[t]{2}{*}{ Diff. in serv. share } & & & & $-0.012^{*}$ & & -0.008 \\
\hline & & & & $(0.067)$ & & $(0.257)$ \\
\hline$M A X L$ & & & & & & $-0.400^{* * *}$ \\
\hline \multirow[t]{2}{*}{$M A X K$} & & & & & & 0.083 \\
\hline & & & & & & $(0.568)$ \\
\hline \multirow[t]{2}{*}{ Bilateral trade } & & & & & & -0.002 \\
\hline & & & & & & $(0.952)$ \\
\hline \multirow[t]{2}{*}{ Dum EU } & & & & & & -0.06 \\
\hline & & & & & & $(0.362)$ \\
\hline \multirow[t]{2}{*}{$T S C$} & $0.443^{* *}$ & & & & & $0.517^{* * *}$ \\
\hline & $(0.000)$ & & & & & $(0.000)$ \\
\hline \multirow[t]{2}{*}{ Cst } & -0.042 & $0.276^{* * *}$ & $0.246^{* * *}$ & $0.283^{* * *}$ & $0.234^{* * *}$ & $-2.396^{* *}$ \\
\hline & $(0.699)$ & $(0.001)$ & $(0.009)$ & $(0.002)$ & $(0.005)$ & $(0.011)$ \\
\hline \multirow{3}{*}{$\begin{array}{l}\text { Obs. } \\
R^{2} \\
\frac{\sigma^{2}(\widehat{Y})}{\sigma^{2}(Y)}\end{array}$} & 723 & 723 & 647 & 706 & 723 & 635 \\
\hline & 0.062 & 0.038 & 0.045 & 0.041 & 0.036 & 0.112 \\
\hline & 0.356 & 0.340 & 0.372 & 0.348 & 0.338 & 0.424 \\
\hline \multicolumn{7}{|c|}{$p$-values in parenthesis } \\
\hline \multicolumn{7}{|c|}{${ }^{*}$ significant at $10 \%{ }^{* *}$ significant at $5 \% ;{ }^{* * *}$ significant at $1 \%$} \\
\hline \multicolumn{7}{|c|}{ Country-pair fixed effects and time dummies included but not reported } \\
\hline
\end{tabular}


Table 7: Sensitivity analysis

\begin{tabular}{|c|c|c|c|c|c|}
\hline \multirow{3}{*}{ Model } & \multicolumn{5}{|c|}{ Dependent variable: cross-country GDP correlation } \\
\hline & I & II & III & IV & $\mathrm{V}$ \\
\hline & $\mathrm{BR}$ & No TE & No FE & No FE, cluster & No TE \& FE \\
\hline \multirow[t]{2}{*}{ Diff. in epl } & -0.094 & -0.059 & -0.028 & -0.028 & -0.016 \\
\hline & $(0.170)$ & $(0.386)$ & $(0.402)$ & $(0.351)$ & $(0.592)$ \\
\hline \multirow[t]{2}{*}{ Diff. in $t w$} & $-0.478^{*}$ & $-0.676^{* * *}$ & $-0.233^{*}$ & $-0.233^{*}$ & $-0.267^{* *}$ \\
\hline & $(0.058)$ & $(0.007)$ & $(0.083)$ & $(0.074)$ & $(0.040)$ \\
\hline \multirow[t]{2}{*}{ Diff. in $c o$} & 0.060 & 0.022 & $-0.067^{* *}$ & $-0.067^{* *}$ & $-0.076^{* * *}$ \\
\hline & $(0.352)$ & $(0.733)$ & $(0.018)$ & $(0.013)$ & $(0.004)$ \\
\hline \multirow[t]{2}{*}{ Diff. in $u d n e t$} & 0.159 & 0.072 & 0.029 & 0.029 & 0.029 \\
\hline & $(0.422)$ & $(0.715)$ & $(0.756)$ & $(0.755)$ & $(0.750)$ \\
\hline \multirow[t]{2}{*}{ Diff. in $b r r$} & 0.036 & 0.047 & -0.001 & -0.001 & 0.010 \\
\hline & $(0.861)$ & $(0.823)$ & $(0.994)$ & $(0.994)$ & $(0.937)$ \\
\hline \multirow[t]{2}{*}{$M A X L$} & $-0.400^{* * *}$ & $-0.258^{* *}$ & 0.004 & 0.004 & 0.003 \\
\hline & $(0.006)$ & $(0.050)$ & $(0.581)$ & $(0.602)$ & $(0.668)$ \\
\hline \multirow[t]{2}{*}{$M A X K$} & 0.083 & 0.073 & -0.033 & $-0.033^{*}$ & -0.021 \\
\hline & $(0.568)$ & $(0.396)$ & $(0.106)$ & $(0.085)$ & $(0.249)$ \\
\hline \multirow[t]{2}{*}{ Bilateral trade } & -0.002 & -0.002 & 0.008 & 0.008 & 0.010 \\
\hline & $(0.952)$ & $(0.954)$ & $(0.143)$ & $(0.282)$ & $(0.159)$ \\
\hline \multirow[t]{2}{*}{ Dum EU } & -0.060 & -0.097 & 0.055 & 0.055 & 0.048 \\
\hline & $(0.362)$ & $(0.139)$ & $(0.137)$ & $(0.143)$ & $(0.172)$ \\
\hline \multirow[t]{2}{*}{$T S C$} & $0.517^{* * *}$ & $0.568^{* * *}$ & $0.328^{* * *}$ & $0.328^{* * *}$ & $0.379^{* * *}$ \\
\hline & $(0.000)$ & $(0.000)$ & $(0.001)$ & $(0.001)$ & $(0.000)$ \\
\hline \multirow[t]{2}{*}{ Diff. in budget } & $-0.019^{* *}$ & $-0.015^{*}$ & $-0.020^{* * *}$ & $-0.020^{* * *}$ & $-0.017^{* * *}$ \\
\hline & $(0.036)$ & $(0.096)$ & $(0.001)$ & $(0.002)$ & $(0.006)$ \\
\hline \multirow[t]{2}{*}{ Diff. in int. rate } & $-0.025^{* *}$ & -0.000 & -0.005 & -0.005 & 0.007 \\
\hline & $(0.039)$ & $(0.987)$ & $(0.543)$ & $(0.579)$ & $(0.359)$ \\
\hline \multirow[t]{2}{*}{ Diff. in serv. share } & -0.008 & -0.002 & -0.001 & -0.001 & -0.001 \\
\hline & $(0.257)$ & $(0.747)$ & $(0.575)$ & $(0.547)$ & $(0.645)$ \\
\hline \multirow[t]{2}{*}{ Diff. in Quinn's index } & 0.001 & $0.002^{*}$ & 0.00 & 0.00 & 0.00 \\
\hline & $(0.256)$ & $(0.080)$ & $(0.623)$ & $(0.588)$ & $(0.614)$ \\
\hline \multirow[t]{2}{*}{ Cst } & $-2.396^{* *}$ & $-1.583^{* *}$ & 0.191 & 0.191 & 0.133 \\
\hline & $(0.011)$ & $(0.031)$ & $(0.112)$ & $(0.108)$ & $(0.219)$ \\
\hline Obs. & 635 & 635 & 635 & 635 & 635 \\
\hline$R^{2}$ & 0.112 & 0.080 & 0.125 & 0.125 & 0.111 \\
\hline$\frac{\sigma^{2}(\widehat{Y})}{\sigma^{2}(Y)}$ & 0.4237 & 0.4012 & 0.1311 & 0.1311 & 0.1157 \\
\hline \multicolumn{6}{|c|}{$p$-values in brackets, BR (Benchmark Results), TE (Time Effect), FE (Fixed Effect) } \\
\hline \multicolumn{6}{|c|}{${ }^{*}$ significant at $10 \% ;{ }^{* *}$ significant at $5 \% ;{ }^{* * *}$ significant at $1 \%$} \\
\hline \multicolumn{6}{|c|}{ In columns IV and V, estimation is run by clustering observations by country pair } \\
\hline
\end{tabular}


Table 8: Exploring the role of interactions across LMI

\begin{tabular}{|c|c|c|c|c|c|}
\hline \multirow[b]{2}{*}{ Model } & \multicolumn{5}{|c|}{ Dependent variable: cross-country GDP correlation } \\
\hline & $\mathrm{I}$ & II & III & IV & $\mathrm{V}$ \\
\hline \multirow[t]{2}{*}{ Diff. in $e p l$} & -0.070 & -0.080 & -0.075 & -0.093 & -0.082 \\
\hline & $(0.311)$ & $(0.238)$ & $(0.265)$ & $(0.174)$ & $(0.247)$ \\
\hline \multirow[t]{2}{*}{ Diff. in $t w$} & -0.266 & $-0.504^{*}$ & $-0.856^{* * *}$ & $-0.563^{*}$ & $-0.783^{* *}$ \\
\hline & $(0.387)$ & $(0.100)$ & $(0.008)$ & $(0.060)$ & $(0.040)$ \\
\hline \multirow[t]{2}{*}{ Diff. in $c o$} & 0.037 & 0.052 & 0.024 & 0.037 & 0.033 \\
\hline & $(0.623)$ & $(0.512)$ & $(0.752)$ & $(0.623)$ & $(0.681)$ \\
\hline \multirow[t]{2}{*}{ Diff. in udnet } & -0.014 & -0.001 & 0.149 & -0.015 & 0.115 \\
\hline & $(0.943)$ & $(0.997)$ & $(0.487)$ & $(0.941)$ & $(0.598)$ \\
\hline \multirow[t]{2}{*}{ Diff. in $b r r$} & 0.160 & 0.122 & 0.143 & 0.153 & 0.137 \\
\hline & $(0.449)$ & $(0.575)$ & $(0.496)$ & $(0.493)$ & $(0.550)$ \\
\hline \multirow[t]{2}{*}{ Both epl rigid } & $0.258 * *$ & & & & $0.235^{* *}$ \\
\hline & $(0.026)$ & & & & $(0.045)$ \\
\hline \multirow[t]{2}{*}{ Diff. in $t w^{*}$ Both epl rigid } & $-1.285^{* *}$ & & & & $-1.164^{* *}$ \\
\hline & $(0.011)$ & & & & $(0.026)$ \\
\hline \multirow[t]{2}{*}{ Both co low } & & 0.074 & & & 0.093 \\
\hline & & $(0.670)$ & & & $(0.595)$ \\
\hline \multirow[t]{2}{*}{ Diff. in $t w^{*}$ Both co low } & & -0.041 & & & -0.250 \\
\hline & & $(0.958)$ & & & $(0.751)$ \\
\hline \multirow[t]{2}{*}{ Both udnet high } & & & -0.110 & & -0.109 \\
\hline & & & $(0.314)$ & & $(0.325)$ \\
\hline \multirow[t]{2}{*}{ Diff. in $t w^{*}$ Both udnet high } & & & $1.491^{* *}$ & & $1.478^{* *}$ \\
\hline & & & $(0.012)$ & & $(0.015)$ \\
\hline \multirow[t]{2}{*}{ Both brr high } & & & & -0.074 & -0.091 \\
\hline & & & & $(0.414)$ & $(0.333)$ \\
\hline \multirow[t]{2}{*}{ Diff. in $t w^{*}$ Both $b r r$ high } & & & & 0.519 & 0.645 \\
\hline & & & & $(0.271)$ & $(0.192)$ \\
\hline \multirow[t]{2}{*}{ Both $t w$ high } & & & & & -0.087 \\
\hline & & & & & $(0.289)$ \\
\hline$M A X L$ & $\begin{array}{c}-0.416^{* *} \\
(0.035)\end{array}$ & $\begin{array}{c}-0.451^{* *} \\
(0.024)\end{array}$ & $\begin{array}{c}-0.461^{* *} \\
(0.020)\end{array}$ & $\begin{array}{c}-0.430^{* *} \\
(0.030)\end{array}$ & $\begin{array}{c}-0.472^{* *} \\
(0.018)\end{array}$ \\
\hline$T S C_{2}$ & $\begin{array}{c}0.528^{* * *} \\
(0.000)\end{array}$ & $\begin{array}{c}0.528^{* * *} \\
(0.000)\end{array}$ & $\begin{array}{c}0.535^{* * *} \\
(0.000)\end{array}$ & $\begin{array}{c}0.517^{* * *} \\
(0.000)\end{array}$ & $\begin{array}{c}0.525^{* * *} \\
(0.000)\end{array}$ \\
\hline Diff. in budget & $\begin{array}{c}-0.019 * * \\
(0.046)\end{array}$ & $\begin{array}{c}-0.019 * * \\
(0.048)\end{array}$ & $\begin{array}{c}-0.020^{* *} \\
(0.043)\end{array}$ & $\begin{array}{c}-0.018^{*} \\
(0.066)\end{array}$ & $\begin{array}{c}-0.020 * * \\
(0.044)\end{array}$ \\
\hline Diff. in int. rate & $\begin{array}{c}-0.025^{* *} \\
(0.043)\end{array}$ & $\begin{array}{c}-0.022^{*} \\
(0.067)\end{array}$ & $\begin{array}{c}-0.023^{*} \\
(0.057)\end{array}$ & $\begin{array}{c}-0.022^{*} \\
(0.079)\end{array}$ & $\begin{array}{c}-0.025 * * \\
(0.043)\end{array}$ \\
\hline Cst & $\begin{array}{c}-2.367^{* *} \\
(0.035)\end{array}$ & $\begin{array}{c}-2.542^{* *} \\
(0.026)\end{array}$ & $\begin{array}{c}-2.571^{* *} \\
(0.022)\end{array}$ & $\begin{array}{c}-2.387^{* *} \\
(0.035)\end{array}$ & $\begin{array}{c}-2.624^{* *} \\
(0.022)\end{array}$ \\
\hline \multirow{3}{*}{$\begin{array}{l}\text { Obs. } \\
R^{2} \\
\frac{\sigma^{2}(\widehat{Y})}{\sigma^{2}(Y)}\end{array}$} & 610 & 610 & 610 & 610 & 610 \\
\hline & 0.116 & 0.102 & 0.117 & 0.104 & 0.137 \\
\hline & 0.429 & 0.419 & 0.421 & 0.430 & 0.444 \\
\hline \multicolumn{6}{|l|}{$p$-values in brackets } \\
\hline \multicolumn{6}{|c|}{${ }^{*}$ significant at $10 \% ;{ }^{* *}$ significant at $5 \% ;{ }^{* * *}$ significant at $1 \%$} \\
\hline
\end{tabular}

